\title{
Minireview
}

\section{Strategies for Developing $\kappa$ Opioid Receptor Agonists for the Treatment of Pain with Fewer Side Effects}

\author{
Kelly F. Paton, ${ }^{1}$ Diana V. Atigari, ${ }^{1}$ Sophia Kaska, Thomas Prisinzano, and Bronwyn M. Kivell \\ School of Biological Sciences, Centre for Biodiscovery, Victoria University of Wellington, Wellington, New Zealand (K.P., D.V.A., \\ B.M.K.) and Department of Pharmaceutical Sciences, University of Kentucky, Lexington, Kentucky (S.K., T.P.)
}

Received May 28, 2020; accepted August 27, 2020

\section{ABSTRACT}

There is significant need to find effective, nonaddictive pain medications. $\kappa$ Opioid receptor (KOPr) agonists have been studied for decades but have recently received increased attention because of their analgesic effects and lack of abuse potential. However, a range of side effects have limited the clinical development of these drugs. There are several strategies currently used to develop safer and more effective $\mathrm{KOPr}$ agonists. These strategies include identifying G-protein-biased agonists, developing peripherally restricted KOPr agonists without centrally mediated side effects, and developing mixed opioid agonists, which target multiple receptors at specific ratios to balance side-effect profiles and reduce tolerance.
Here, we review the latest developments in research related to KOPr agonists for the treatment of pain.

\section{SIGNIFICANCE STATEMENT}

This review discusses strategies for developing safer $\kappa$ opioid receptor (KOPr) agonists with therapeutic potential for the treatment of pain. Although one strategy is to modify selective $\mathrm{KOPr}$ agonists to create peripherally restricted or G-protein-biased structures, another approach is to combine $\mathrm{KOPr}$ agonists with $\mu, \delta$, or nociceptin opioid receptor activation to obtain mixed opioid receptor agonists, therefore negating the adverse effects and retaining the therapeutic effect.

\section{Introduction}

The rapid increase in the use of opioid drugs in the United States has been termed the "opioid crisis," with over 47,000 opioid-related deaths in 2017 (Scholl et al., 2018). Opioids prescribed for treating moderate-to-severe pain act primarily through the $\mu$ opioid receptor (MOPr) (Vallejo et al., 2011). Activation of the MOPr stimulates the mesocorticolimbic reward pathway, thereby increasing dopamine levels (Di Chiara and Imperato, 1988), and results in positive reinforcement (Maldonado et al., 1997). In the search for nonaddictive analgesics, $\kappa$ opioid receptor (KOPr) agonists are a promising alternative. In contrast to MOPr agonists, KOPr agonists play a critical role in regulating the reward system by contributing to the negative feedback of dopamine (Di Chiara and Imperato, 1988),

This work was supported by the Health Research Council of New Zealand, B.M.K. [Grant 16/646] and National Institutes of Health National Institute on Drug Abuse [Grant RO1: DA018151] (to T.E.P.). K.F.P. and D.V.A. each received a doctoral scholarship from Victoria University of Wellington.

${ }^{1}$ K.F.P. and D.V.A. contributed equally to this work.

https://doi.org/10.1124/jpet.120.000134. and unlike MOPr agonists, they do not cause respiratory depression (Freye et al., 1983).

\section{$\kappa$ Opioid Receptor Signaling and the Role in Pain}

Activation of the KOPr is associated with regulation of the reward pathway, antinociception, and anxiogenic and stress-related behaviors [reviewed in Wang et al, (2010), Lalanne et al. (2014)]. The KOPr is a class A (rhodopsin-like) $\gamma$ subfamily of seven-transmembrane G-protein-coupled receptors. Activation of the KOPr leads to conformational changes and dissociation of the pertussis toxin-sensitive G-protein subunits, thereby activating G-protein-gated inwardly rectifying potassium channels (Grudt and Williams, 1993) and inhibiting voltage-gated calcium ion channels (Rusin et al., 1997), which leads to the hyperpolarization of the neuron. The $\mathrm{G} \alpha$ subunit inhibits adenylyl cyclase activity, leading to a decrease in cAMP (Taussig et al., 1993) and phosphorylation of c-Jun N-terminal kinase and extracellular signal-regulated kinase 1 and 2 (ERK1/2) (Belcheva et al., 2005). KOPrs inhibit pain signals in the spinal cord and the brain stem (Porreca et al., 1984; Ruda et al., 1988; Simonin et al., 1995).

ABBREVIATIONS: ATPM, 3-amino-thiazolo [5,4-b]-N-cyclopropylmethylmorphinan hydrochloride; 8-CAC, 8-carboxamidocyclazocine; CPA, conditioned place aversion; DOPr, $\delta$ opioid receptor; EOM, ethoxymethyl ether; ERK1/2, extracellular signal-regulated kinase 1 and 2; 6'-GNTI, 6'-guanidinonaltrindole; HEK-293, human embryonic kidney-293; KOPr, $\kappa$ opioid receptor; MOPr, $\mu$ opioid receptor; NOPr, nociceptin opioid receptor; SalA, Salvinorin A; SalB, Salvinorin B; $\beta$-THP, $\beta$-tetrahydropyran. 
KOPr activation also activates a $\beta$-arrestin-dependent signaling cascade. The $\mathrm{C}$-terminal intracellular domain is phosphorylated by G-protein receptor kinase 3, and the $\beta$-arrestin scaffolding proteins are recruited, leading to the phosphorylation of p38 mitogen-activated protein kinase and activation of the transcription factor cAMP response element binding protein (McLaughlin et al., 2003; Bruchas et al., 2006). Prodepressive and aversive effects of KOPr agonists have been attributed to the phosphorylation of p38 mitogen-activated protein kinase (Bruchas et al., 2007, 2011; Ehrich et al., 2015) and cAMP response element binding protein activity (Pliakas et al., 2001; Mague et al., 2003). Phosphorylation of KOPr leads to the internalization of the receptor (Schulz et al., 2002), contributing to KOPr agonist tolerance (McLaughlin et al., 2004; Chiu et al., 2017).

KOPr knockout mice were generated by Simonin et al. (1998). These animals have been tested in a range of behavioral models of pain, showing increased sensitivity in the acetic acid writhing test, thus indicating the KOPr system is involved in the perception of visceral pain. The endogenous agonists for the KOPr are the dynorphin class of opioid peptides (Goldstein et al., 1979; Chavkin et al., 1982). The natural peptide has 17 amino acids (dynorphin $\mathrm{A}_{1-17}$ ); however, the shortened 13-amino-acid fragment (dynorphin $\mathrm{A}_{1-13}$ ) is often used in biologic studies (Chou et al., 1996). Intrathecal injection of dynorphin $A_{1-13}$ in the rat spinal cord had an antinociceptive effect 6-10 times more potent than morphine on a molar basis (Han and Xie, 1982), and morphine in combination with dynorphin $\mathrm{A}_{1-13}$ produced a synergistic antinociceptive effect in the tailwithdrawal assay (Ren et al., 1985).

In the reward centers, such as the nucleus accumbens, KOPr activation regulates dopamine release and increases uptake by the dopamine transporter (Di Chiara and Imperato, 1988; Kivell et al., 2014). This mechanism is responsible for the antiaddiction effects of KOPr agonism; however, aversive effects can also be induced (Wee and Koob, 2010), and drug-taking can be escalated due to KOPr activation (Schlosburg et al., 2013). During pain, negative affect states may be mediated by recruitment of dynorphin neurons and action through the KOPr system in the nucleus accumbens (Massaly et al., 2019). In a spinal nerve ligation model, experiments using prodynorphin knockout mice showed dynorphin may be required for the maintenance of neuropathic pain (Wang et al., 2001). Further studies have shown that the KOPr system is involved in the aversive component of neuropathic pain (Liu et al., 2019b; Meade et al., 2020).

\section{Traditional Arylacetamide $\kappa$ Opioid Receptor Agonists}

The prototypical arylacetamide KOPr agonists include U50,488 (Von voigtlander and Lewis, 1982), U69,593 (Lahti et al., 1985), and spiradoline (also known as U62,066E; Fig. 1) (Vonvoigtlander and Lewis, 1988). The KOPr agonists have demonstrated antinociceptive effects in several thermal, inflammatory, and neuropathic pain models (Vonvoigtlander et al., 1983; Calcagnetti et al., 1988; La Regina et al., 1988; Vonvoigtlander and Lewis, 1988; Kunihara et al., 1989; Pelissier et al., 1990; France et al., 1994; Wilson et al., 1996; Bartok and Craft, 1997; Catheline et al., 1998; Binder et al., 2001; Bileviciute-Ljungar and Spetea, 2004; BileviciuteLjungar et al., 2006; Gallantine and Meert, 2008; Negus et al., 2008; Auh and Ro, 2012). Unfortunately, these KOPr agonists also have side effects. U50,488 and U69,593 produce prodepressive effects (Mague et al., 2003; Zhang et al., 2015), aversion (Mucha and Herz, 1985; Suzuki et al., 1992; BalsKubik et al., 1993; Skoubis et al., 2001; Ehrich et al., 2015), anxiety (Privette and Terrian, 1995; Kudryavtseva et al., 2004; Vunck et al., 2011; Wang et al., 2016), muscle weakness, and sedation (Dykstra et al., 1987; Zhang et al., 2015). In clinical studies, spiradoline produced diuresis, sedation, and dysphoria (Ur et al., 1997; Wadenberg, 2003). Because of these side effects, these arylacetamide KOPr agonists have not been developed further in the clinical setting.

\section{Strategies to Develop $\kappa$ Opioid Receptor Agonists with Reduced Side Effects}

There are several strategies used to develop novel, safer, and more effective KOPr agonists. These strategies include identifying G-protein-biased agonists, developing peripherally restricted KOPr agonists without centrally mediated side effects, and developing mixed opioid agonists to target multiple receptors at specific ratios to balance side-effect profiles and reduce tolerance.

\section{G-Protein-Biased $\kappa$ Opioid Receptor Agonists}

Evidence suggests that many KOPr side effects are mediated through $\beta$-arrestin-dependent pathways (Bruchas and Chavkin, 2010). For instance, in mice lacking G-protein receptor kinase 3, aversion is absent (Bruchas et al., 2007). Therefore, developing biased KOPr agonists with preferential activation of the G-protein pathway has received significant attention [reviewed by Mores et al. (2019)]. Biased agonism is calculated by evaluating activation in both G-protein and
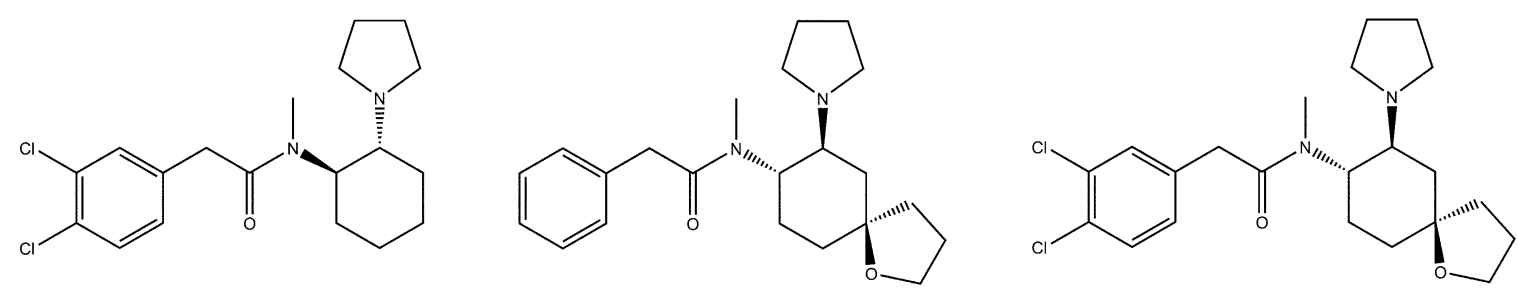

Fig. 1. Chemical structure of the traditional arylacetamide $\kappa$ opioid receptor agonists, U50,488, U69,593, and Spiradoline. 
$\beta$-arrestin signaling pathways and comparing affinity and efficacy to a reference agonist with balanced signaling properties. The biased factors of common KOPr agonists are presented in Table 1.

However, application of the theoretical idea of biased agonism has proven more difficult than anticipated (Michel and Charlton, 2018). When comparing studies, there is a lack of consistency in signaling assays, cell types, and choice of reference ligands, including use of U50,488 (Schattauer et al., 2017; Kivell et al., 2018), U69,593 (Ho et al., 2018; Dunn et al., 2019), Salvinorin A (SalA) (White et al., 2015), or the endogenous peptide dynorphin $\mathrm{A}_{1-17}$ (DiMattio et al., 2015). In addition, receptors from different species have different signaling properties. DiMattio et al. (2015) calculated the bias factor in N2A cells stably transfected with either the human or mouse KOPr. SalA was significantly $\beta$-arrestin-biased for the human receptor; however, the mouse KOPr had similar activation of both pathways. On the contrary, U50,488 was $\beta$-arrestin-biased at the mouse receptor but was unbiased at the human KOPr.

System bias (cell background) and observational bias (assay conditions) in experimental design create further complications (Gundry et al., 2017). Observational bias problems include not accounting for intrinsic efficacy and using both amplified and linear signaling measurements (Gillis et al., 2020b). Using in vitro models, there is often high receptor expression, thus commonly producing a ceiling effect within the assay whereby most agonists will reach the maximal effect, therefore not allowing for comparisons of efficacy. When receptor pools are lowered, the intrinsic efficacy of the agonist may be measured. G-protein measurements often use amplified assays (such as cAMP), whereas $\beta$-arrestin recruitment assays are not amplified. In this situation, the results are skewed toward G-protein bias. Furthermore, the kinetic context (Klein Herenbrink et al., 2016), receptor occupancy, and receptor conformation (Kenakin, 2014) are not often considered. Most experiments assess an agonist at a single time point, which may be based on the reference ligand. However, this does not allow for the complexity of the binding kinetics and transient signaling responses (Klein Herenbrink et al., 2016). As seen in Table 1, the most commonly used model to calculate bias is the operational model (Black and Leff, 1983); however, for this calculation to be correct, system and observational bias must not be present in the data. Many laboratories are addressing system bias issues and are beginning to evaluate signaling in more relevant cellular models, including primary neurons (Jamshidi et al., 2015; Ho et al., 2018; Ehrlich et al., 2019). A major limiting factor is the inability to evaluate signaling bias in vivo, although advances are ongoing, such as measuring cAMP signaling in mice (Muntean et al., 2018).

The MOPr has been extensively studied [for recent review see Grim et al. (2020)] and may be able to guide the development of G-protein-biased KOPr agonists. Raehal et al. (2005) showed the respiratory depressive effects and constipation caused by morphine were not present in $\beta$-arrestin-2 knockout mice. This led to much attention on developing G-protein-biased agonists. However, it was recently shown in three different laboratories that the respiratory depressive effects of morphine were independent of $\beta$-arrestin-2 signaling (Kliewer et al., 2020). There is a similar story with the compound PZM21, which was originally shown to have few side effects (Manglik et al., 2016) and has since been shown to have respiratory depression (Hill et al., 2018). Finally, the G-protein-biased MOPr agonist oliceridine (TRV130 or Olinvyk) completed phase III clinical trials; originally, the drug was not approved because of safety concerns (https://www.fda.gov/media/121233/download). Interestingly, Gillis et al. (2020a) found that low intrinsic efficacy rather than G-protein bias could explain the reduced side effects of oliceridine and PZM21, therefore leaving the question as to whether apparent G-protein-biased MOPr agonists need to be reassessed under these experimental conditions. Regardless of mechanism, evaluation of drugs at higher doses in vivo is required to fully assess both safety and side effects.

These discrepancies need to be resolved before conclusions can be drawn on the role of G-protein-biased KOPr agonists for treating pain with fewer side effects. However, several KOPr agonists have been identified with improved side-effect profiles.

Nalfurafine. Nalfurafine (or TRK-820, Fig. 2) is the first selective KOPr agonist to be clinically approved for medicationresistant pruritus in patients with hemodialysis in Japan (Kumagai et al., 2010). Nalfurafine has antinociceptive and antipruritic effects (Endoh et al., 1999, 2000) and does not produce anhedonia or aversion (Liu et al., 2019a). The success of nalfurafine has demonstrated it is possible to develop KOPr agonists to be used in a clinical setting. Many studies have sought to measure the bias factor to understand the lack of side effects traditionally associated with KOPr agonists; however, there have been mixed results (Table 1). In human embryonic kidney-293 (HEK-293) cells, nalfurafine was a G-protein-biased agonist compared with U50,488 (Kaski et al., 2019), with moderate G-protein bias at the rat KOPr and extreme G-protein bias at the human KOPr (Schattauer et al., 2017). However, a recent paper found nalfurafine was a balanced agonist compared with U50,488 as the reference ligand (Liu et al., 2019a), and another found nalfurafine was $\beta$-arrestin-2-biased, with 20 -fold-higher $\beta$-arrestin signaling than U69,593 in U2OS cells (Dunn et al., 2019).

Salvinorin A Analogs. The neo-clerodane diterpene SalA (Fig. 2) is a KOPr agonist derived from Salvia divinorum, a Sage plant native to Mexico (Valdés, 1994; Roth et al., 2002). SalA has antinociceptive effects in thermal (John et al., 2006; McCurdy et al., 2006; Paton et al., 2017; Sherwood et al., 2017), visceral (McCurdy et al., 2006; Fichna et al., 2012), inflammatory (Aviello et al., 2011; Fichna et al., 2012; Guida et al., 2012; Paton et al., 2017), and neuropathic pain models (Coffeen et al., 2018). However, side effects include aversion (Zhang et al., 2005), anxiety (Braida et al., 2009), prodepressive effects (Carlezon et al., 2006), motor incoordination (Fantegrossi et al., 2005), sedation (Butelman et al., 2009), and learning and memory impairments (Braida et al., 2011). SalA also has a short duration of action in vivo (Butelman et al., 2007; Ranganathan et al., 2012). All these effects have limited the clinical usefulness of SalA. However, the structural scaffold of SalA has identified multiple analogs with improvements in metabolic stability and side-effect profile.

Modifications at the carbon-2 position have led to increased potency by adding metabolism-protective groups and removing the hydrolysable ester (Munro et al., 2008). These include 
TABLE 1

$\kappa$ Opioid receptor agonists with G-protein bias

1) White et al., 2014. 2) Dunn et al., 2019. 3) Dunn et al., 2018. 4) DiMattio et al., 2015. 5) White et al., 2015. 6) Liu et al., 2019a. 7) Schattauer et al., 2017. 8) Kaski et al., 2019. 9) Kivell et al., 2018. 10) Zhou et al., 2013. 11) Lovell et al., 2015. 12) Brust et al., 2016. 13) Ho et al., 2018. 14) Schmid et al., 2013. 15) Stahl et al., 2015. 16) Spetea et al., 2017. 17) Bedini et al., 2020.

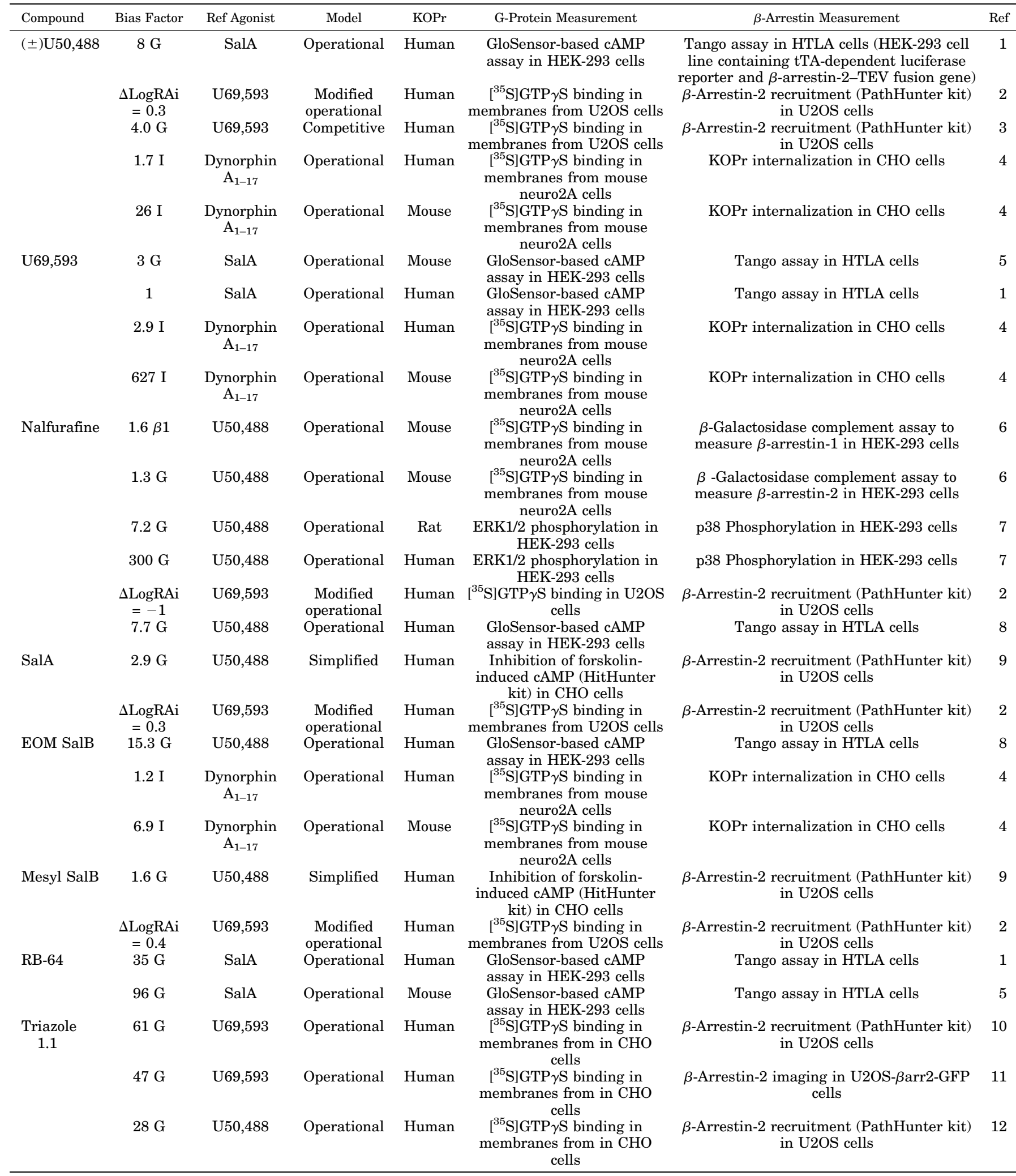


TABLE 1-Continued

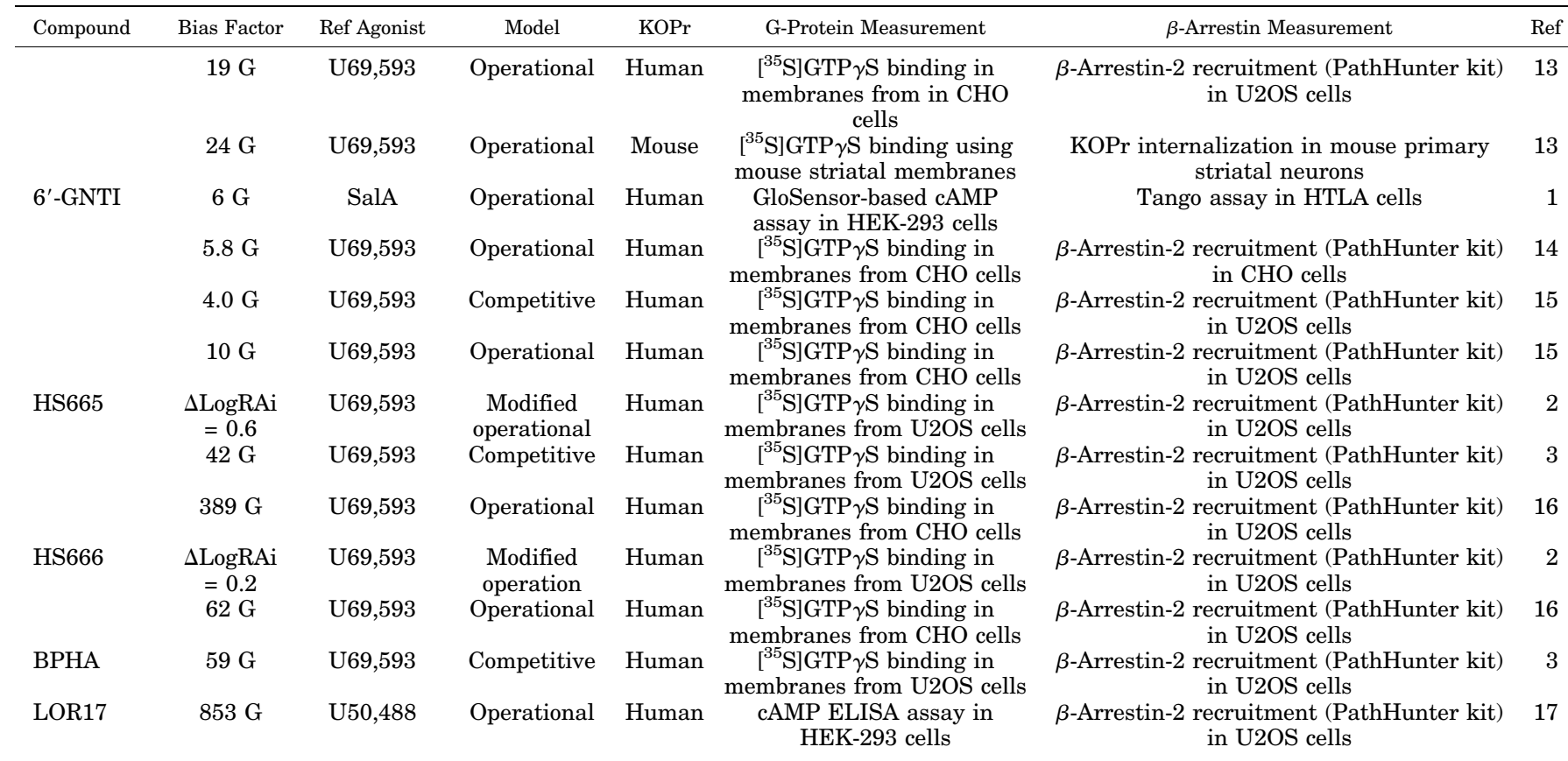

1) White et al., 2014. 2) Dunn et al., 2019. 3) Dunn et al., 2018. 4) DiMattio et al., 2015. 5) White et al., 2015. 6) Liu et al., 2019a. 7) Schattauer et al., 2017. 8) Kaski et al., 2019.

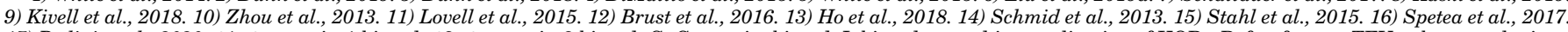

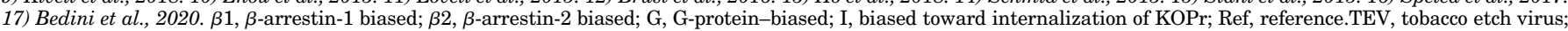
tTA, tetracycline transactivator.

$\beta$-tetrahydropyran ( $\beta$-THP) Salvinorin B (SalB), Mesyl SalB, and ethoxymethyl ether (EOM) SalB (Fig. 2). Mesyl SalB and EOM are G-protein-biased at the human KOPr using U50,488 as a reference ligand (Kivell et al., 2018; Kaski et al., 2019). However, EOM SalB was also found to be $\beta$-arrestin-biased at the mouse KOPr with dynorphin $\mathrm{A}_{1-17}$ as the reference ligand (DiMattio et al., 2015).

Compared with SalA, EOM SalB has higher metabolic stability in the rat liver microsome assay (Ewald et al., 2017), and brain concentrations declined at a slower rate in baboons and rats (Hooker et al., 2009). EOM SalB, Mesyl SalB, and $\beta$-THP SalB all have a longer duration of action than SalA in the warm-water tail-withdrawal assay in mice (Simonson et al., 2015; Paton et al., 2017). $\beta$-THP SalB reduced mechanical and cold allodynia in the chemotherapy-induced neuropathic pain model and significantly reduced formaldehyde-induced pain behaviors (Paton et al., 2017), whereas Mesyl SalB had minimal effects (Kivell et al., 2018). Mesyl SalB produced no aversion, anxiety, or learning and memory impairments (Kivell et al., 2018). EOM SalB did not cause sedation, anxiety, or depressive-like effects in rodents (Ewald et al., 2017). However, in discrimination studies, EOM SalB substituted for both U69,593 (Baker et al., 2009) and SalA in rats (Peet and Baker, 2011).

A semisynthetic analog, RB-64 (22-thiocyanatosalvinorin A, Fig. 2) (Yan et al., 2009), is G-protein-biased compared with SalA as the reference ligand (White et al., 2014, 2015). In C57BL/6J mice, RB-64 had antinociceptive effects in the hotplate $\left(55^{\circ} \mathrm{C}\right)$ assay and did not show anhedonia-like effects in the intracranial self-stimulation test or locomotor deficits in the Rotarod performance assay or novelty-induced locomotion test (White et al., 2015). However, RB-64 did have aversive effects in the conditioned place aversion (CPA) paradigm, an effect previously believed to be $\beta$-arrestin-mediated (Bruchas and Chavkin, 2010; White et al., 2015).

Collybolide. Collybolide (Fig. 2) is a selective $\mathrm{KOPr}$ agonist extracted from the mushroom Collybia maculata (Gupta et al., 2016). The chemical structure is similar to SalA in that both are terpene compounds containing a furyl$\delta$-lactone structure. In HEK-293 cells expressing the human $\mathrm{KOPr}$, displacement of the $\left[{ }^{3} \mathrm{H}\right] \mathrm{U} 69,593$ radioligand showed binding affinity $\left(\mathrm{K}_{\mathrm{i}}\right)$ values of $40 \pm 10 \mathrm{nM}$ for SalA compared with $9 \pm 2 \mathrm{nM}$ for Collybolide (Gupta et al., 2016). In mice, Collybolide had similar antinociceptive effects to SalA in tail withdrawal, was not prodepressive in the forced swim test, did not affect locomotor activity in open field tests, and was not anxiogenic in the elevated plus maze; however, there was significant aversion in the CPA test (Gupta et al., 2016). Moreover, Collybolide, unlike SalA, also attenuated chloroquinemediated pruritus (Gupta et al., 2016).

Triazole 1.1. A high-throughput screening process was used to identify selective KOPr agonists in a library of 300,000 compounds (Frankowski et al., 2012). Triazole 1.1 (Fig. 2) was identified as a G-protein-biased KOPr agonist compared with U69,593 (Zhou et al., 2013; Lovell et al., 2015). Triazole 1.1 displayed antinociceptive effects in the warm-water tailwithdrawal assay (Zhou et al., 2013) and antipruritic effects in response to chloroquine phosphate (Brust et al., 2016). Moreover, Triazole 1.1 showed an improved side-effect profile. It did not alter locomotor activity nor induce dysphoria in the intracranial self-stimulation assay, did not lower dopamine levels in the nucleus accumbens (Brust et al., 2016), and did not induce sedation or motor impairment in male rhesus monkeys (Huskinson et al., 2020).

6'-Guanidinonaltrindole. The naltrindole derivative $6^{\prime}$-guanidinonaltrindole $\left(6^{\prime}\right.$-GNTI) (Fig. 2) is a potent partial 


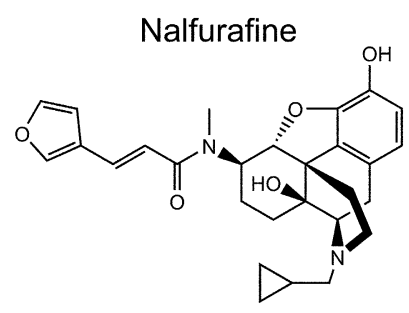

SalA<smiles>COC(=O)[C@H]1C[C@@H](OC(C)=O)C(=O)[C@@H]2[C@@H]3C[C@H](c4ccoc4)OC(=O)[C@@]3(C)CC[C@]12C</smiles>

EOM SalB<smiles>CCOCO[C@H]1C[C@H](C(=O)OC)[C@@]2(C)CC[C@]3(C)C(=O)O[C@H](c4ccoc4)C[C@H]3[C@@]2(C)C1=O</smiles><smiles></smiles><smiles>COC(=O)[C@H]1C[C@H](OS(C)(=O)=O)C(=O)[C@@H]2[C@@H]3C[C@H](c4ccoc4)OC(=O)[C@@]3(C)CC[C@]12C</smiles>

RB-64

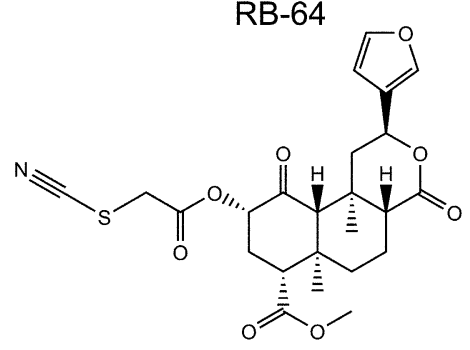

Fig. 2. Chemical structures of the G-protein-biased $\kappa$ opioid receptor agonists.

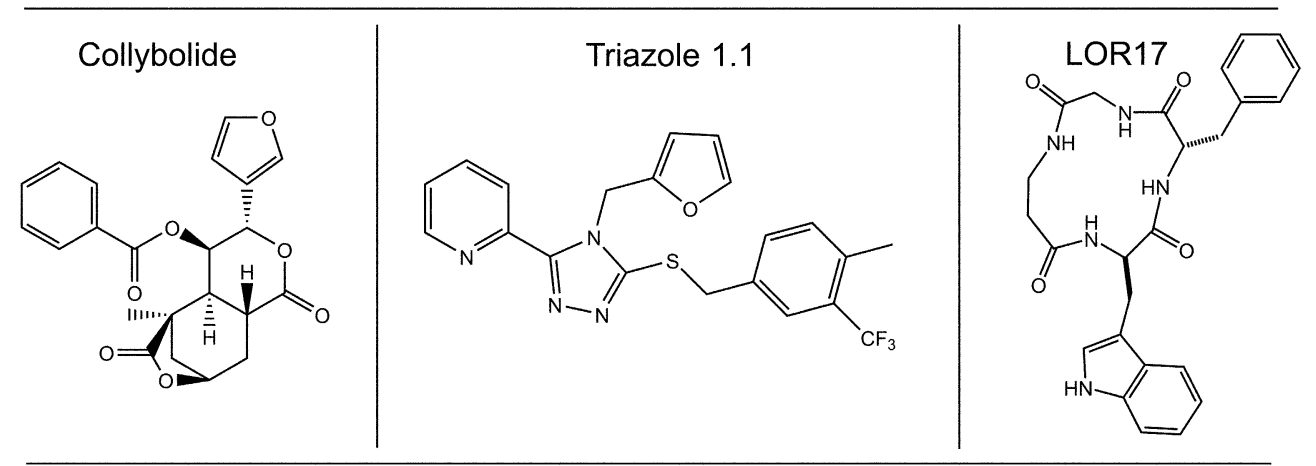

HS666<smiles>Oc1cccc(CCN(CCc2ccccc2)CC2CCC2)c1</smiles><smiles>Oc1cccc(CCN(CCc2ccccc2)CC2CC2)c1</smiles>

BPHA<smiles>CCCCN(CCc1ccccc1)CCc1cccc(O)c1</smiles>

KOPr agonist in G-protein activation assays, with no activity in $\beta$-arrestin recruitment assays (Rives et al., 2012). In fact, $6^{\prime}$ GNTI inhibited both the $\beta$-arrestin recruitment and the KOPr internalization actions of the KOPr agonist ethylketocyclazocine (Rives et al., 2012). Furthermore, in striatal neurons,
6'-GNTI induced the phosphorylation of Akt but not ERK1/2 compared with the traditional agonist U69,593, which activated both kinases (Schmid et al., 2013). It appears that the $\delta$ opioid receptor (DOPr) has a role in the function of $6^{\prime}$-GNTI, either because of actions on KOPr/DOPr heterodimers or 
convergence of downstream signaling pathways (Waldhoer et al., 2005; Jacobs et al., 2019). 6'-GNTI has antinociceptive effects in the radiant-heat tail-withdrawal assay in male mice (Waldhoer et al., 2005) and did not display CPA (Zangrandi et al., 2016).

Diphenethyalmine Derivatives. The diphenethylamine derivatives, HS665 (also known as MCBPHA) and HS666 (Fig. 2), are selective KOPr agonists (Spetea et al., 2012) displaying G-protein bias with $\mathrm{U} 69,593$ as the reference agonist (Spetea et al., 2017; Dunn et al., 2018). Both compounds produced dose-dependent antinociception in the warm-water $\left(55^{\circ} \mathrm{C}\right)$ tail withdrawal and did not produce motor incoordination in Rotarod assays (Spetea et al., 2017). HS665 also had antinociceptive effects in the acetic acid-induced writhing test in mice (Spetea et al., 2012). HS665 had aversive side effects; however, HS666 did not show either aversion or preference in a counterbalanced conditioned place paradigm (Spetea et al., 2017). Another derivative, $N$ - $n$-butyl- $N$-phenylethyl- $N$-3-hydroxyphenylethyl-amine (BPHA), did not recruit $\beta$-arrestin compared with HS665, which showed submaximal $\beta$-arrestin signaling, and this was correlated with altered motor coordination for HS665 but not BPHA (Dunn et al., 2018, 2019). Additional diphenethylamine derivatives have been developed with promising antinociceptive effects in the acetic acid-induced writhing assay without causing motor incoordination (Erli et al., 2017).

LOR17. LOR17 is a novel peptidic KOPr agonist displaying extreme G-protein bias with U50,488 as the reference ligand (Bedini et al., 2020). In male CD-1 mice, LOR17 had similar antinociceptive effects to U50,488 in the warm-water tail withdrawal and acetic acid-induced writhing test, whereas LOR17 was more effective at reducing thermal hypersensitivity in the oxaliplatin-induced neuropathic pain model (Bedini et al., 2020). LOR17 did not affect motor coordination in the Rotarod test or exploratory behavior in the hole-board test and did not have prodepressant effects in the forced swim test (Bedini et al., 2020).

\section{Peripherally Restricted $\kappa$ Opioid Receptor Agonists}

Another strategy to remove the centrally mediated side effects is to create peripherally restricted KOPr agonists that do not cross the blood-brain barrier. This strategy relies on the premise that activation of peripheral KOPrs alone can produce a meaningful analgesic effect. Peripherally restricted compounds can be beneficial to patients suffering from visceral or neuropathic pain. However, many of the compounds tested only have moderate antinociceptive effects. One of the first developed was ICI 204,448 (Fig. 3) (Shaw et al., 1989). In a rat model of neuropathic pain, local injection of ICI 204,448 reduced antinociceptive behaviors after sciatic nerve constriction injury (Keïta et al., 1995). However, ICI 204,448 had minimal effects in the formaldehyde-induced inflammatory pain model in mice when administered via intraperitoneal injection (1-2 mg/kg) (Paton et al., 2017) and minimal antinociceptive activity after oral administration (Barber et al., 1994).

Another KOPr agonist with low central penetration is asimadoline (Fig. 3; also known as EMD 61753) (Barber et al., 1994; Gottschlich et al., 1995). Asimadoline is orally active, although it had more potent antinociceptive activity after subcutaneous administration (Barber et al., 1994). When it advanced into human testing, oral administration of asimadoline $(7.5 \mathrm{mg}$ ) had no effect in hyperalgesia models using radiant heat and mechanical stimuli (Bickel et al., 1998). Furthermore, when tested in patients with postoperative pain, some of those administered $10 \mathrm{mg}$ orally reported increased pain levels, and therefore, asimadoline was considered to be less tolerable than placebo (Machelska et al., 1999). Asimadoline is currently in development by Tioga Pharmaceuticals for the treatment of atopic dermatitis [reviewed in Abels and Soeberdt (2019)].

CR845 (also known as FE-202845 or Difelikefalin) and CR665 (also known as FE-200665 or JNJ-38488502) are peripherally restricted tetrapeptide KOPr agonists (Fig. 3) in development by Cara Therapeutics (Olesen et al., 2013). CR845 is in phase III clinical trials as a treatment of postoperative pain and uremic pruritus (Beck et al., 2019a). There are promising results in animal models, with CR845 reducing writhing behaviors, abdominal pain, inflammatory pain, and mechanical allodynia in a spinal nerve ligation model of neuropathic pain without inducing gastrointestinal side effects (Gardell et al., 2008). However, there is a lack of peer-reviewed papers on the clinical efficacy of this compound (Hesselink, 2017). CR665 has antinociceptive effects in the complete Freund's adjuvant-induced model of inflammatory pain (Binder et al., 2001) and the acetic acid-induced writhing test in mice, with a 548-fold-higher dose required to induce centrally mediated motor incoordination effects, indicating it does not readily cross the blood-brain barrier (Vanderah et al., 2008). Intravenous CR665 (0.36 mg/kg) was effective at reducing visceral pain in a human model of esophageal distension (Arendt-Nielsen et al., 2009); however, CR665 (0.42 mg/kg, i.v.) did not reduce pain in a colonic distension model (Floyd et al., 2009).

CR665 is not orally active, and therefore, structural alterations have been made to improve the oral bioavailability. One of the derivatives (compound 9) reduced acetic acid-induced writhing behaviors in male Sprague-Dawley rats with no effect on centrally mediated hot-plate pain after oral administration $(30 \mathrm{mg} / \mathrm{kg})$, indicating a peripheral site of action (Hughes et al., 2013). This compound has been renamed JT09 (Fig. 3) and is currently in development by JT Pharmaceuticals. In the follow-up paper, the acetic acid writhing test was repeated, showing that $20 \mathrm{mg} / \mathrm{kg}$ JT09 via oral gavage had the same effect as $10 \mathrm{mg} / \mathrm{kg}$ morphine (Beck et al., 2019b). JT09 was not self-administered by rats and showed no CPA, indicating no rewarding effects (Beck et al., 2019b). Finally, there were no prodepressive effects in the forced swim test model, nor sedative effects in the spontaneous locomotor test (Beck et al., 2019b). The authors state that further work is planned to understand the pharmacodynamics of JT09 and to assess the antinociceptive effects in chronic pain models.

Peripherally restricted derivatives of nalfurafine are also in development by Toray Industries (Suzuki et al., 2017). There are a range of compounds with an increased number of hydrogen bond donors, including 17-hydroxy-cyclopropylmethyl (compound 8) and 10 $\alpha$-hydroxy (compound 10) (Fig. 3), yielding promising results. The two compounds are highly selective for the KOPr over the MOPr; in fact, compound 8 had $>5,200,000$ times greater selectivity for the KOPr (Suzuki et al., 2017). To assess brain penetration, the brain-plasma concentration ratio $\left(K_{\mathrm{p}, \text { brain }}\right)$ was calculated 15 minutes after intravenous 
injection in male ICR mice. Nalfurafine had a ratio of 0.41 , and the novel compounds had lower brain penetrations; compound 8 was 0.11 , and compound 10 was 0.07 (Suzuki et al., 2017). Finally, the compounds were tested in the acetic acid writhing model in mice, with both producing dose-dependent antiallodynic effects (Suzuki et al., 2017). These hydroxy nalfurafine compounds have encouraging results so far; however, further in vivo experiments are required to fully evaluate the
ICI 204,448<smiles>CN(C(=O)Cc1ccc(Cl)c(Cl)c1)C(CN1CCCC1)c1cccc(OCC(=O)O)c1</smiles>

\section{Asimadoline}<smiles>CN(C(=O)C(c1ccccc1)c1ccccc1)[C@H](CN1CC[C@H](O)C1)c1ccccc1</smiles>

\section{CR845}<smiles>CC(C)C[C@H](NC(=O)[C@H](Cc1ccccc1)NC(=O)[C@H](N)Cc1ccccc1)C(=O)N[C@@H](CCCCN)C(=O)N1CCC(N)(C(=O)O)CC1</smiles><smiles>CCCC[C@H](NC(=O)[C@H](Cc1ccccc1)NC(=O)[C@H](N)Cc1ccccc1)C(=O)N[C@@H](CCCNC(=N)N)C(=O)NCc1ccncc1</smiles>

JT09<smiles>CCCC[C@H](NC(=O)[C@H](Cc1ccccc1)NC(=O)[C@H](N)Cc1ccccc1)C(=O)N[C@@H](CCCCN(C)C)C(=O)NCc1ccncc1</smiles>

17-hydroxy-cyclopropylmethyl derivative (compound 8)<smiles>CN(C(=O)/C=C/c1ccoc1)[C@H]1CC[C@@]2(O)[C@H]3Cc4ccc(O)c5c4[C@@]2(CCN3CC2(CC2)C5)[C@H]1O</smiles>

10a-hydroxy derivative

(compound 10)

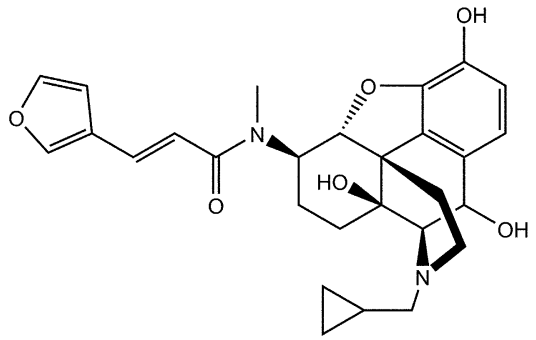

Fig. 3. Chemical structures of the peripherally restricted $\kappa$ opioid receptor agonists. 
antinociceptive potential and confirm there are no centrally mediated side effects.

Despite the number of compounds that have been tested, there has been some criticism of this strategy. One limitation with developing peripherally restricted pain medications is that the blood-brain barrier must be intact; however, the blood-brain barrier becomes more permeable in some chronic pain conditions (DosSantos et al., 2014). Furthermore, peripherally restricted $\mathrm{KOPr}$ agonists can reduce pain-related stimulation of behavior; however, there is a lack of evidence that these compounds block pain-related depression of behavior (Negus, 2019). In Sprague-Dawley rats, two peripherally restricted KOPr agonists, ICI 204,448 and the tetrapeptide ffir, had weak and no antinociceptive effect, respectively, in a lactic-acid depressed intracranial self-stimulation assay (Negus et al., 2012), whereas the nonsteroidal antiinflammatory drug, ketoprofen, had significant effect in this assay (Negus et al., 2012). Further studies are required to understand the effect of peripherally restricted KOPr agonists in these assays of pain-related depression of behavior.

\section{Mixed $\kappa$ Opioid Receptor Agonists}

The final strategy used to overcome the undesirable effects of $\mathrm{KOPr}$ agonism is to target multiple opioid receptors simultaneously. The four classes of opioid receptors MOPr, KOPr, DOPr, and nociceptin opioid receptors (NOPrs) all modulate pain (McDonald and Lambert, 2005; Dietis et al., 2011; Darcq and Kieffer, 2018). Mixed opioid receptor agonists may be a viable strategy to develop analgesics with reduced side effects (Balboni et al., 2002; Váradi et al., 2016; Majumdar and Devi, 2018). Mixed agonists could maintain antinociceptive effects, with the KOPr-mediated dysphoric or aversivelike effects balanced by the euphoric properties of MOPr or DOPr activation.

\section{Mixed KOPr/MOPr Compounds}

KOPr/MOPr Full Agonism. 8-Carboxamidocyclazocine (8-CAC) is a full agonist at both $\mathrm{KOPr}$ and MOPr, with potent, long-acting antinociceptive effects in male ICR mice at nanomolar doses in warm-water tail-withdrawal and acetic acidinduced writhing tests $\left(\mathrm{ED}_{50}=0.21 \mathrm{nmol}\right.$, i.c.v.) (Bidlack et al., 2002). In addition, 8-CAC produced antinociception that lasted for 15 hours in the writhing test (Bidlack et al., 2002). Acute administration of 8-CAC blocked cocaine-maintained responding and decreased food-maintained responding. In contrast, chronic administration increased cocaine selfadministration in rhesus monkeys (Stevenson et al., 2004), indicating that 8-CAC may have abuse potential when administered chronically.

Combined KOPr Agonism and Partial MOPr Agonism. Butorphan (MCL-101), is a KOPr agonist with partial MOPr agonist actions that reduced the rewarding effects of cocaine in rats (Provencher et al., 2013) and rhesus monkeys (Bowen et al., 2003). Neumeyer et al. (2000) found that Butorphan produced potent antinociceptive effects in male ICR mice in warm-water tail-withdrawal $\left(\mathrm{ED}_{50}=7.3 \mathrm{nmol}\right.$, i.c.v. $)$ and acetic acid-induced writhing tests $\left(\mathrm{ED}_{50}=0.79\right.$ nmol, i.c.v., Table 2).

The macrocyclic tetrapeptide CJ-15,208 (cyclo [Phe-D-Pro-PheTrp]) is a natural product with centrally acting multifunctional
KOPr/MOPr agonist and KOPr antagonist actions. CJ-15,208 produced antinociception without displaying hypolocomotor effects in the Rotarod test in mice after oral administration (Ross et al., 2010; Aldrich et al., 2013). Its analog, cyclo [ProSar-Phe-D-Phe] also displayed similar antinociceptive effects with reduced side effects compared with morphine (Brice-Tutt et al., 2020; Ferracane et al., 2020). Of interest, the alanine analogs of [D-Trp]CJ-15,208 displayed pharmacological profiles in vivo that were distinctly different from the parent compound. Although the analogs exhibited varying opioid receptor activities in vitro, they produced potent opioid receptor-mediated antinociception $\left(\mathrm{ED}_{50}=0.28-4.19 \mathrm{nmol}\right.$, i.c.v.) in vivo in mice (Aldrich et al., 2014).

Discrepancies between in vitro binding affinity and in vivo efficacy and potency are not uncommon, and it is possible that metabolism may account for many of these observed differences. Another possibility is allosteric modulation. For example, BMS-986122 is a positive allosteric modulator for MOPr, and BMS-986187 is a structurally distinct positive allosteric modulator for DOPr (with 100-fold selectivity in promoting DOPr over MOPr). Livingston et al. (2018) also provide evidence that selective allosteric modulators may enhance signaling bias.

KOPr Agonism with MOPr Antagonism. The mixed KOPr agonist and partial MOPr antagonist nalbuphine has potent antinociceptive effects in male (Pick et al., 1992; Patrick et al., 1999; Ortiz et al., 2007) and female mice (Wong and Wai, 1984), rabbits (Yoa-Pu et al., 1998), and humans (Kshirsagar et al., 2008) in a wide range of pain models (Table 2). Moreover, nalbuphine attenuates cocaine abuserelated effects in men (Mello et al., 2005) with lower respiratory depression and fewer psychomimetic side effects compared with other narcotic analgesics, such as nalorphine or pentazocine (Schmidt et al., 1985). Similarly, 3-aminothiazolo [5,4-b]- $N$-cyclopropylmethylmorphinan hydrochloride (ATPM) attenuated heroin self-administration in male Sprague-Dawley rats (Wang et al., 2009) and, along with the analog [(-)-3- $N$-ethyl]-ATPM, showed antinociceptive effects and inhibited morphine-induced antinociceptive tolerance in mice (Wang et al., 2009; Sun et al., 2010) (Table 2).

Although mixed KOPr agonists and partial MOPr antagonists have been proposed as nonaddictive analgesics, some have abuse potential and adverse side effects. For example, pentazocine has analgesic effects in moderate-to-severe pain in humans with mild respiratory depressive effects and did not induce nalorphine-like psychoactive or morphine-like reward behaviors (Sadove et al., 1964). Pentazocine was also effective in patients that underwent a nasal irritation pain model (Lotsch et al., 1997) and in thermal and pressure pain assays (Fillingim et al., 2004) (Table 2). However, the analgesic effects of pentazocine were not as potent as morphine and produced side effects, including hallucinations, disorientation, respiratory depression (Miller, 1975), and abuse potential (Pawar et al., 2015).

Similarly, levallorphan is a KOPr agonist and MOPr antagonist that blocked the euphoric effects of morphine while retaining antinociceptive effects via KOPr meditation in male CD1 mice (Codd et al., 1995). Moreover, it was found to be protective against respiratory depression (Pawar et al., 2015). However, levallorphan, because of actions at KOPr, can produce hallucinations, dissociation, and other psychotomimetic effects (Hall, 2012). 

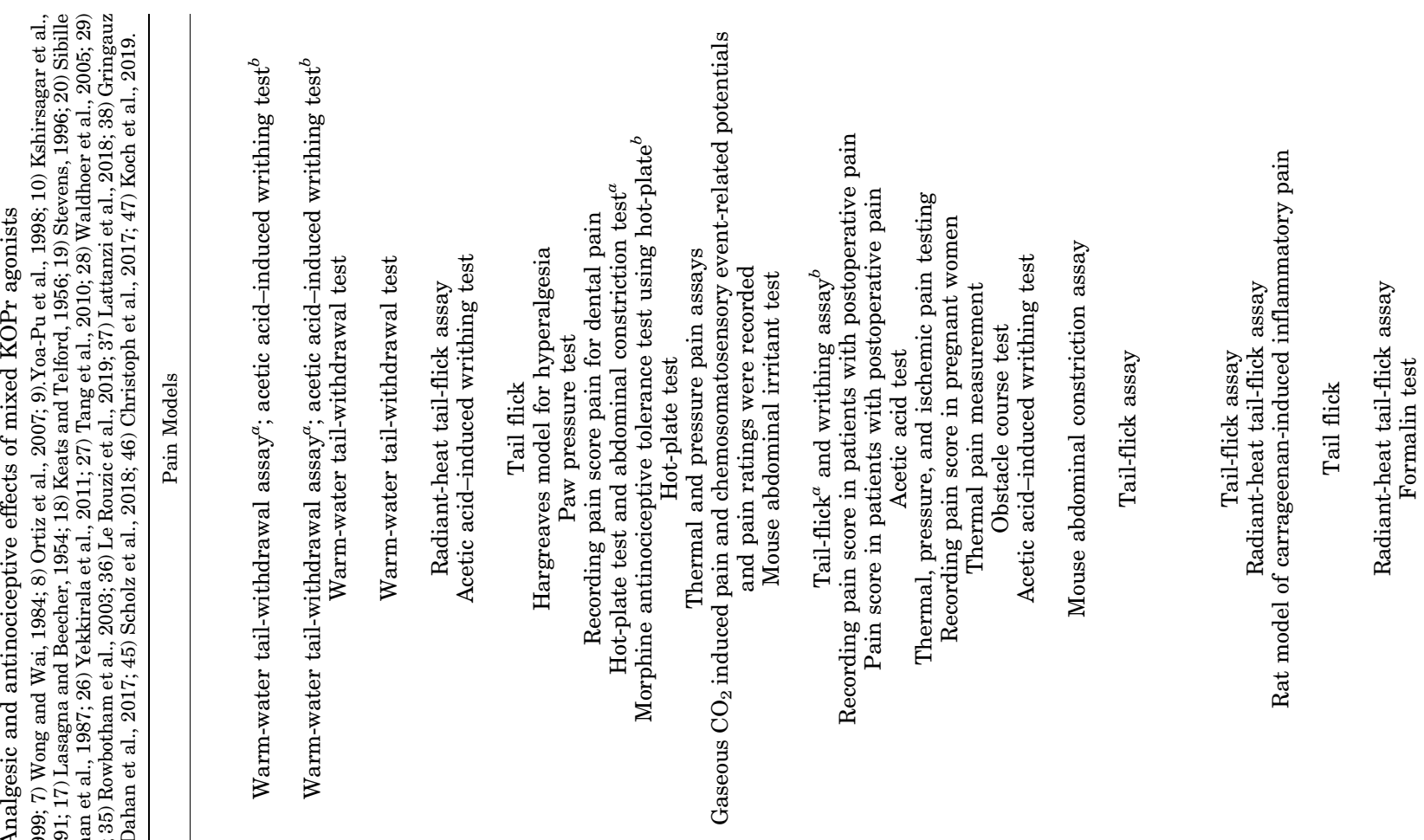

采兽竞

कi

可和和

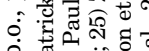

iे 0

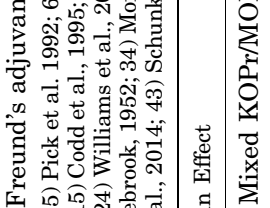

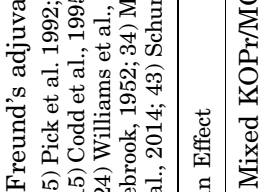

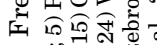

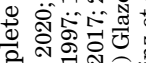

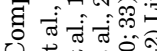

य

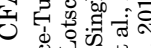

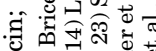

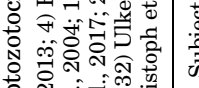

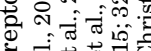

ช

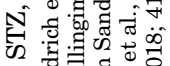

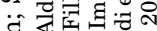

ลิ

.0.

สं สं

प廿

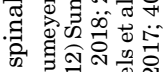

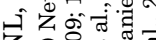

乙 ลิ

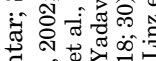

สี ส่

v 密

四

बู

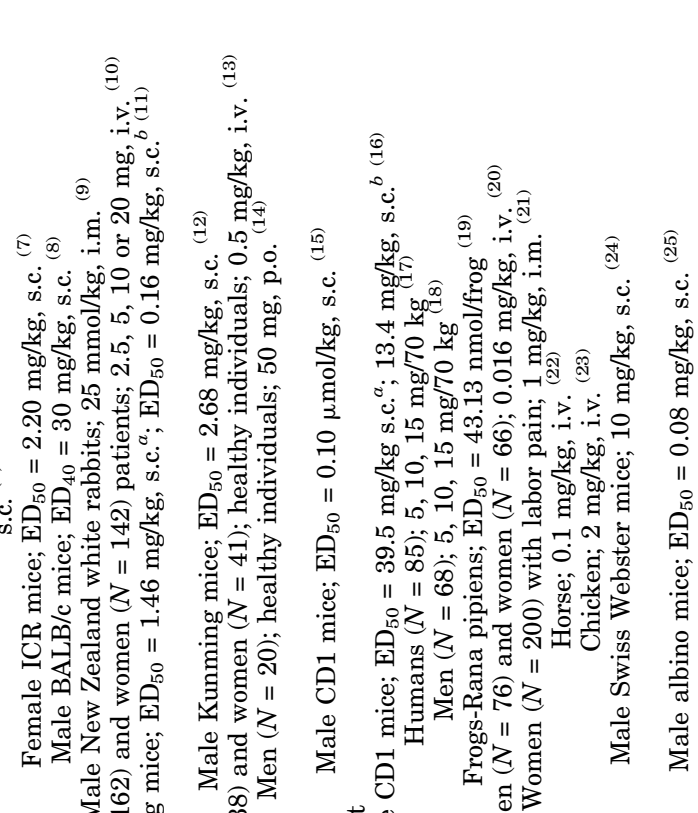

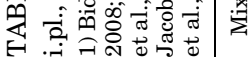

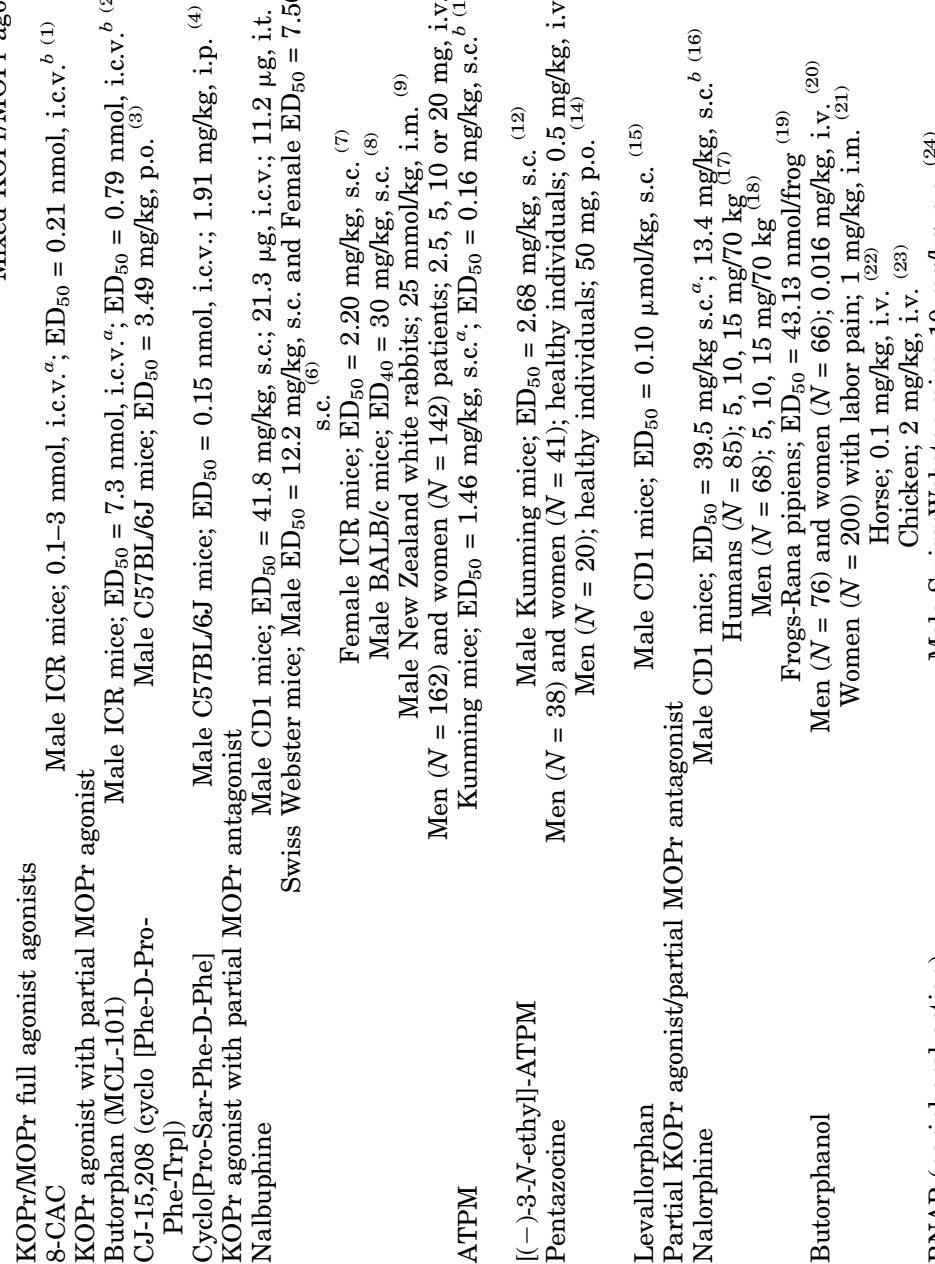

要 


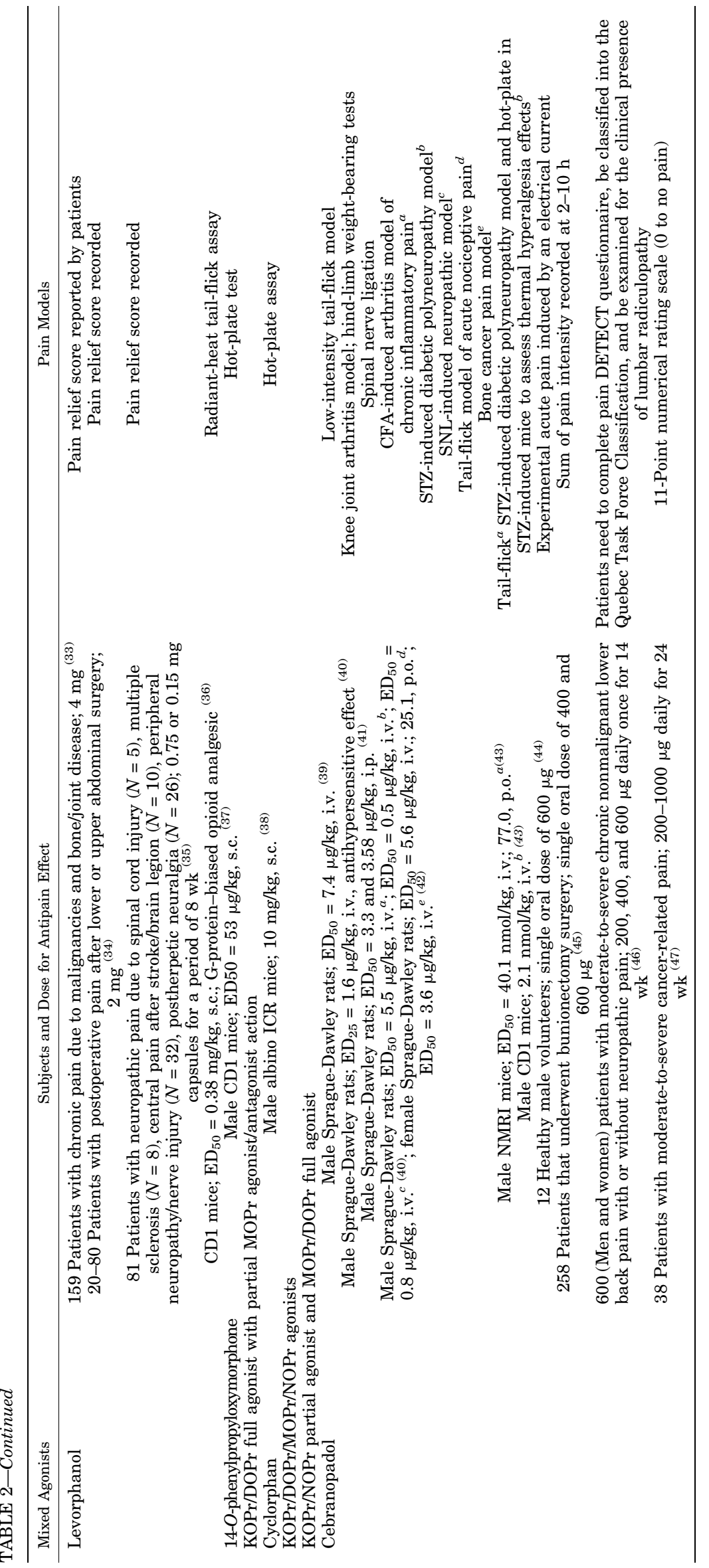


Partial KOPr Agonism with Partial MOPr Agonism/ Antagonism. Nalmefene, nalorphine, and butorphanol are weak partial KOPr agonists with partial MOPr antagonism and have been studied extensively. A clinical study reported that low dose of nalmefene enhanced morphine analgesia in patients with postsurgical pain (Crain and Shen, 2000). Likewise, nalorphine has potent antinociceptive effects in mice (Paul et al., 1991) and analgesic effects in humans (Lasagna and Beecher, 1954; Keats and Telford, 1956) (Table 2); however, clinical development was ceased because of diuresis (Leander, 1983). Butorphanol is used to treat labor pain in pregnant women (Halder and Agarwal, 2013; Haiying et al., 2018; Yadav et al., 2018). In nondependent heroin-using males, acute administration of butorphanol produced little or no physical dependence compared with morphine; however, it did cause dysphoria, hallucinations, and sedation (Tennant et al., 1976; Greenwald and Stitzer, 1998; Pandya, 2010).

$6 \beta-N-H e t e r o c y c l i c$ Substituted Naltrexamine Derivative (BNAP) is another example of an MOPr antagonist and partial $\mathrm{KOPr}$ agonist. BNAP is a peripherally restricted naltrexamine derivative (Williams et al., 2016) with potent antinociceptive effects in male ICR-CD1 mice (Williams et al., 2016) (Table 2). An example of a mixed partial KOPr/MOPr agonist is proxorphan, which produced antinociceptive effects in male albino mice in the abdominal constriction assay (Zimmerman et al., 1987; Hayes and Birch, 1988) (Table 2).

KOPr/MOPr Heteromer. $N$-naphthoyl- $\beta$-naltrexamine is a highly selective and potent activator of $\mathrm{MOPr} / \mathrm{KOPr}$ heteromer and had potent antinociceptive effects in male ICR-CD1 mice in the tail-withdrawal assay (Yekkirala et al., 2011) (Table 2).

\section{Mixed KOPr/DOPr Compounds}

Miaskowski et al. (1990) found that KOPr (U50,488) and DOPr [D- Pen ${ }^{2}$,D- Pen ${ }^{5}$ ]enkephalin agonists administered via intrathecal injection produced a synergistic antinociceptive response. Although DOPr agonists can produce seizures (Comer et al., 1993; Bilsky et al., 1995; Jutkiewicz et al., 2006; Lutz and Kieffer, 2013) and have abuse potential (Shippenberg et al., 2009; Pradhan et al., 2011; Mori et al., 2015), KOPr agonists have anticonvulsant, antiseizure (Zangrandi et al., 2016), and antiaddiction effects (Negus et al., 1997; Mello and Negus, 2000). Therefore, it is hypothesized that mixed KOPr and DOPr agonism could have fewer side effects.

A novel analog of 3-iodobenzoyl naltrexamine called MP1104 has dual KOPr/DOPr agonist actions (Váradi et al., 2015). MP1104 produced potent antinociceptive effects in the radiant-heat tail-withdrawal assay in male CD1 mice (Váradi et al., 2015) and reduced inflammatory pain in the intradermal formalin test in both male and female ICR mice (Ulker et al., 2020) (Table 2). Moreover, MP1104 has anticocaine effects in male Sprague-Dawley rats and showed no anxiogenic, prodepressive, or aversive side effects (Atigari et al., 2019).

There are also compounds created to target KOPr/DOPr heterodimers. These include KDA-16 (also known as ICI199,441), which showed spinal antinociception via selective activation of KOPr-DOPr heterodimers in mice (Tang et al., 2010). KDAN-18, which links KOPr agonist ICI199,441 and DOPr antagonist naltrindole, produced antinociceptive effects in tail-withdrawal assays in male mice (Daniels et al., 2005). As mentioned previously, 6'-GNTI selectively activated DOPr/KOPr heterodimers but not KOPr or DOPr homomers (Waldhoer et al., 2005). Together, this suggests that opioid receptor heterodimers are distinct functional signaling units and could provide a target for the development of tissueselective analgesics with reduced side effects.

\section{Mixed KOPr/DOPr/MOPr Compounds}

Levorphanol is a full agonist at both MOPr and DOPr and a partial KOPr agonist (Le Rouzic et al., 2019). Levorphanol was effective in treating chronic pain resulting from malignancies and bone or joint disease (Glazebrook, 1952) and postoperative pain after abdominal surgery (Morrison et al., 1971). In addition, as a strong $N$-methyl-D-aspartate receptor antagonist (Pham et al., 2015), levorphanol has inhibitory effects on the uptake of serotonin and norepinephrine, which makes it suitable to be used for the treatment of neuropathic pain (Rowbotham et al., 2003; Zorn and Fudin, 2011). Levorphanol has been investigated for potential clinical uses for treating chronic pain (McNulty, 2007) and opioid-induced hyperalgesia [Stringer et al., 2000; for full review of levorphanol see Gudin et al. (2016)]. Recently, it was shown that the antinociceptive actions of levorphanol were mediated via G-protein-biased MOPr agonism (Le Rouzic et al., 2019). Furthermore, levorphanol produced significantly less respiratory depression than morphine at equal doses (Le Rouzic et al., 2019).

Cyclorphan has mixed weak partial MOPr agonist and antagonist activity in combination with KOPr and DOPr agonism. Cyclorphan had antinociceptive effects in mice in the hot-plate assay (Gringauz et al., 2001) with long-acting antinociceptive effects; however, adverse psychomimetic effects prevented its clinical development (Varghese and Hudlicky, 2014).

Recently, a potent mixed MOPr/DOPr/KOPr agonist called 14-O-phenylpropyloxymorphone was synthesized by modifying the structure of the MOPr agonist 14-O-methyloxymorphone (Lattanzi et al., 2018). 14-O-phenylpropyloxymorphone produced potent antinociceptive effects in the acute hot-plate assay in mice compared with reduced constipation compared with morphine (Lattanzi et al., 2018). Although 14-O-phenylpropyloxymorphone has high affinity toward all three opioid receptors, the antinociceptive effects were found to be mediated via MOPr only (Lattanzi et al., 2018).

\section{Mixed KOPr/DOPr/MOPr/NOPr Compounds}

Cebranopadol (also known as GRT-60005) is a full agonist at MOPr and DOPr and a partial agonist at KOPr and NOPr and has potent antinociceptive effects in thermal, inflammatory, chronic neuropathic, and bone cancer pain models in male and female rats with a favorable side-effect profile (Linz et al., 2014). Other studies in rodents have reported potent antinociceptive effects in thermal (Schunk et al., 2014; Linz et al., 2017), arthritic (Schiene et al., 2018), and neuropathic pain models (Schunk et al., 2014; Christoph et al., 2018). Cebranopadol is currently in clinical trials for several indications, including treatment of severe chronic nociceptive (Dahan et al., 2017), postoperative (Scholz et al., 2018), chronic lower back (Christoph et al., 2017), cancer (Koch et al., 2019), and 
neuropathic pain (Schunk et al., 2014; Lambert et al., 2015) (Table 2).

\section{Conclusions}

There are hurdles to overcome in the development of KOPr agonists for the treatment of pain. The KOPr activation can drive the negative affective state during inflammatory pain (Massaly et al., 2019) and the aversive component of neuropathic pain (Liu et al., 2019b; Meade et al., 2020). However, this review provides evidence that several KOPr agonists have been developed with preclinical antinociceptive effects with few side effects. These improvements often correlate to enhanced G-protein signaling over $\beta$-arrestin recruitment, although there are clear differences in the determination of signaling bias. An alternative approach to overcome the undesirable effects of selective KOPr agonism is to develop peripherally restricted KOPr agonists or mixed opioid receptor agonists. In particular, a mixed opioid agonist with $\mathrm{MOPr}$ and DOPr activation may reduce the aversive-like effects produced by KOPr agonism.

\section{Authorship Contributions}

Wrote or contributed to the writing of the manuscript: Paton, Atigari, Kaska, Prisinzano, Kivell.

\section{References}

Abels C and Soeberdt M (2019) Can we teach old drugs new tricks?-Repurposing of neuropharmacological drugs for inflammatory skin diseases. Exp Dermatol 28: 1002-1009.

Aldrich JV, Senadheera SN, Ross NC, Ganno ML, Eans SO, and McLaughlin JP (2013) The macrocyclic peptide natural product CJ-15,208 is orally active and prevents reinstatement of extinguished cocaine-seeking behavior. J Nat Prod 76: 433-438.

Aldrich JV, Senadheera SN, Ross NC, Reilley KA, Ganno ML, Eans SE, Murray TF and McLaughlin JP (2014) Alanine analogues of [D-Trp]CJ-15,208: novel opioid activity profiles and prevention of drug- and stress-induced reinstatement of cocaine-seeking behaviour. Br J Pharmacol 171:3212-3222.

Arendt-Nielsen L, Olesen AE, Staahl C, Menzaghi F, Kell S, Wong GY, and Drewes AM (2009) Analgesic efficacy of peripheral kappa-opioid receptor agonist CR665 compared to oxycodone in a multi-modal, multi-tissue experimental human pain model: selective effect on visceral pain. Anesthesiology 111:616-624.

Atigari DV, Uprety R, Pasternak GW, Majumdar S, and Kivell BM (2019) MP1104, a mixed kappa-delta opioid receptor agonist has anti-cocaine properties with reduced side-effects in rats. Neuropharmacology 150:217-228.

Auh QS and Ro JY (2012) Effects of peripheral $\kappa$ opioid receptor activation on inflammatory mechanical hyperalgesia in male and female rats. Neurosci Lett 524: 111-115.

Aviello G, Borrelli F, Guida F, Romano B, Lewellyn K, De Chiaro M, Luongo L, Zjawiony JK, Maione S, Izzo AA, et al. (2011) Ultrapotent effects of salvinorin A, a hallucinogenic compound from Salvia divinorum, on LPS-stimulated murine macrophages and its anti-inflammatory action in vivo. J Mol Med (Berl) 89: 891-902.

Baker LE, Panos JJ, Killinger BA, Peet MM, Bell LM, Haliw LA, and Walker SL (2009) Comparison of the discriminative stimulus effects of salvinorin A and its derivatives to U69,593 and U50,488 in rats. Psychopharmacology (Berl) 203: 203-211.

Balboni G, Guerrini R, Salvadori S, Bianchi C, Rizzi D, Bryant SD, and Lazarus LH (2002) Evaluation of the Dmt-Tic pharmacophore: conversion of a potent $\delta$-opioid receptor antagonist into a potent $\delta$ agonist and ligands with mixed properties. J Med Chem 45:713-720.

Bals-Kubik R, Ableitner A, Herz A, and Shippenberg TS (1993) Neuroanatomical sites mediating the motivational effects of opioids as mapped by the conditioned place preference paradigm in rats. J Pharmacol Exp Ther 264:489-495.

Barber A, Bartoszyk GD, Bender HM, Gottschlich R, Greiner HE, Harting J, Mauler F, Minck KO, Murray RD, Simon M, et al. (1994) A pharmacological profile of the novel, peripherally-selective kappa-opioid receptor agonist, EMD 61753. Br $J$ Pharmacol 113:1317-1327.

Bartok RE and Craft RM (1997) Sex differences in opioid antinociception. J Pharmacol Exp Ther 282:769-778.

Beck TC, Hapstack MA, Beck KR, and Dix TA (2019a) Therapeutic potential of kappa opioid agonists. Pharmaceuticals (Basel) 12:95.

Beck TC, Reichel CM, Helke KL, Bhadsavle SS, and Dix TA (2019b) Non-addictive orally-active kappa opioid agonists for the treatment of peripheral pain in rats. Eur J Pharmacol 856:172396.

Bedini A, Di Cesare Mannelli L, Micheli L, Baiula M, Vaca G, De Marco R, Gentilucci L, Ghelardini C, and Spampinato S (2020) Functional selectivity and antinociceptive effects of a novel KOPr agonist. Front Pharmacol 11:188.
Belcheva MM, Clark AL, Haas PD, Serna JS, Hahn JW, Kiss A, and Coscia CJ (2005) $\mathrm{Mu}$ and kappa opioid receptors activate ERK/MAPK via different protein kinase $\mathrm{C}$ isoforms and secondary messengers in astrocytes. $J$ Biol Chem 280: 27662-27669.

Bickel A, Dorfs S, Schmelz M, Forster C, Uhl W, and Handwerker HO (1998) Effects of antihyperalgesic drugs on experimentally induced hyperalgesia in man. Pain 76: 317-325.

Bidlack JM, Cohen DJ, McLaughlin JP, Lou R, Ye Y, and Wentland MP (2002) 8Carboxamidocyclazocine: a long-acting, novel benzomorphan. J Pharmacol Exp Ther 302:374-380.

Bileviciute-Ljungar I, Saxne T, and Spetea M (2006) Anti-inflammatory effects of contralateral administration of the kappa-opioid agonist U-50,488H in rats with unilaterally induced adjuvant arthritis. Rheumatology (Oxford) 45:295-302.

Bileviciute-Ljungar I and Spetea M (2004) Contralateral, ipsilateral and bilateral treatments with the kappa-opioid receptor agonist U-50,488H in mononeuropathic rats. Eur J Pharmacol 494:139-146.

Bilsky EJ, Calderon SN, Wang T, Bernstein RN, Davis P, Hruby VJ, McNutt RW, Rothman RB, Rice KC, and Porreca F (1995) SNC 80, a selective, nonpeptidic and systemically active opioid delta agonist. J Pharmacol Exp Ther 273:359-366.

Binder W, Machelska H, Mousa S, Schmitt T, Rivière PJ, Junien JL, Stein C, and Schäfer M (2001) Analgesic and antiinflammatory effects of two novel kappaopioid peptides. Anesthesiology 94:1034-1044.

Black JW and Leff P (1983) Operational models of pharmacological agonism. Proc $R$ Soc Lond B Biol Sci 220:141-162.

Bowen CA, Negus SS, Zong R, Neumeyer JL, Bidlack JM, and Mello NK (2003) Effects of mixed-action $\mathrm{k} / \mu$ opioids on cocaine self-administration and cocaine discrimination by rhesus monkeys. Neuropsychopharmacology 28:1125-1139.

Braida D, Capurro V, Zani A, Rubino T, Viganò D, Parolaro D, and Sala M (2009) Potential anxiolytic- and antidepressant-like effects of salvinorin A, the main active ingredient of Salvia divinorum, in rodents. $\mathrm{Br} J$ Pharmacol 157:844-853.

Braida D, Donzelli A, Martucci R, Capurro V, and Sala M (2011) Learning and memory impairment induced by salvinorin A, the principal ingredient of Salvia divinorum, in wistar rats. Int $J$ Toxicol 30:650-661.

Brice-Tutt AC, Wilson LL, Eans SO, Stacy HM, Simons CA, Simpson GG, Coleman JS, Ferracane MJ, Aldrich JV, and McLaughlin JP (2020) Multifunctional opioid receptor agonism and antagonism by a novel macrocyclic tetrapeptide prevents reinstatement of morphine-seeking behaviour. Br J Pharmacol 177:4209-4222.

Bruchas MR and Chavkin C (2010) Kinase cascades and ligand-directed signaling at the kappa opioid receptor. Psychopharmacology (Berl) 210:137-147.

Bruchas MR, Land BB, Aita M, Xu M, Barot SK, Li S, and Chavkin C (2007) Stressinduced p38 mitogen-activated protein kinase activation mediates kappa-opioiddependent dysphoria. J Neurosci 27:11614-11623.

Bruchas MR, Macey TA, Lowe JD, and Chavkin C (2006) Kappa opioid receptor activation of p38 MAPK is GRK3- and arrestin-dependent in neurons and astrocytes. J Biol Chem 281:18081-18089.

Bruchas MR, Schindler AG, Shankar H, Messinger DI, Miyatake M, Land BB, Lemos JC, Hagan CE, Neumaier JF, Quintana A, et al. (2011) Selective p38 $\alpha$ MAPK deletion in serotonergic neurons produces stress resilience in models of depression and addiction. Neuron 71:498-511.

Brust TF, Morgenweck J, Kim SA, Rose JH, Locke JL, Schmid CL, Zhou L, Stahl EL, Cameron MD, Scarry SM, et al. (2016) Biased agonists of the kappa opioid receptor suppress pain and itch without causing sedation or dysphoria. Sci Signal 9:ra117.

Butelman ER, Mandau M, Tidgewell K, Prisinzano TE, Yuferov V, and Kreek MJ (2007) Effects of salvinorin A, a kappa-opioid hallucinogen, on a neuroendocrine biomarker assay in nonhuman primates with high kappa-receptor homology to humans. J Pharmacol Exp Ther 320:300-306.

Butelman ER, Prisinzano TE, Deng H, Rus S, and Kreek MJ (2009) Unconditioned behavioral effects of the powerful kappa-opioid hallucinogen salvinorin A in nonhuman primates: fast onset and entry into cerebrospinal fluid. J Pharmacol Exp Ther 328:588-597.

Calcagnetti DJ, Helmstetter FJ, and Fanselow MS (1988) Analgesia produced by centrally administered DAGO, DPDPE and U50488H in the formalin test. Eur $J$ Pharmacol 153:117-122.

Carlezon WA Jr., Béguin C, DiNieri JA, Baumann MH, Richards MR, Todtenkopf MS, Rothman RB, Ma Z, Lee DY, and Cohen BM (2006) Depressive-like effects of the kappa-opioid receptor agonist salvinorin A on behavior and neurochemistry in rats. J Pharmacol Exp Ther 316:440-447.

Catheline G, Guilbaud G, and Kayser V (1998) Peripheral component in the enhanced antinociceptive effect of systemic U-69,593, a kappa-opioid receptor agonist in mononeuropathic rats. Eur $J$ Pharmacol 357:171-178.

Chavkin C, James IF, and Goldstein A (1982) Dynorphin is a specific endogenous ligand of the kappa opioid receptor. Science 215:413-415.

Chiu YT, Chen C, Yu D, Schulz S, and Liu-Chen LY (2017) Agonist-dependent and -independent $\kappa$ opioid receptor phosphorylation: distinct phosphorylation patterns and different cellular outcomes. Mol Pharmacol 92:588-600.

Chou JZ, Chait BT, Wang R, and Kreek MJ (1996) Differential biotransformation of dynorphin A (1-17) and dynorphin A (1-13) peptides in human blood, ex vivo. Peptides 17:983-990.

Christoph A, Eerdekens MH, Kok M, Volkers G, and Freynhagen R (2017) Cebranopadol, a novel first-in-class analgesic drug candidate: first experience in patients with chronic low back pain in a randomized clinical trial. Pain 158:1813-1824.

Christoph T, Raffa R, De Vry J, and Schröder W (2018) Synergistic interaction between the agonism of cebranopadol at nociceptin/orphanin FQ and classical opioid receptors in the rat spinal nerve ligation model. Pharmacol Res Perspect 6:e00444.

Codd EE, Shank RP, Schupsky JJ, and Raffa RB (1995) Serotonin and norepinephrine uptake inhibiting activity of centrally acting analgesics: structural determinants and role in antinociception. J Pharmacol Exp Ther 274:1263-1270.

Coffeen U, Canseco-Alba A, Simón-Arceo K, Almanza A, Mercado F, León-Olea M, and Pellicer F (2018) Salvinorin A reduces neuropathic nociception in the insular cortex of the rat. Eur J Pain 22:311-318. 
Comer SD, Hoenicke EM, Sable AI, McNutt RW, Chang KJ, De Costa BR, Mosberg HI, and Woods JH (1993) Convulsive effects of systemic administration of the delta opioid agonist BW373U86 in mice. J Pharmacol Exp Ther 267:888-895.

Crain SM and Shen KF (2000) Antagonists of excitatory opioid receptor functions enhance morphine's analgesic potency and attenuate opioid tolerance/dependence liability. Pain 84:121-131.

Dahan A, Boom M, Sarton E, Hay J, Groeneveld GJ, Neukirchen M, Bothmer J, Aarts L, and Olofsen E (2017) Respiratory effects of the nociceptin/orphanin FQ peptide and opioid receptor agonist, cebranopadol, in healthy human volunteers. Anesthesiology 126:697-707.

Daniels DJ, Kulkarni A, Xie Z, Bhushan RG, and Portoghese PS (2005) A bivalent ligand $(\mathrm{KDAN}-18)$ containing $\delta$-antagonist and $\kappa$-agonist pharmacophores bridges $\delta 2$ and $\kappa 1$ opioid receptor phenotypes. J Med Chem 48:1713-1716.

Darcq E and Kieffer BL (2018) Opioid receptors: drivers to addiction? Nat Rev Neurosci 19:499-514.

Di Chiara G and Imperato A (1988) Opposite effects of mu and kappa opiate agonists on dopamine release in the nucleus accumbens and in the dorsal caudate of freely moving rats. J Pharmacol Exp Ther 244:1067-1080.

Dietis N, Rowbotham DJ, and Lambert DG (2011) Opioid receptor subtypes: fact or artifact? $\mathrm{Br} J$ Anaesth 107:8-18.

DiMattio KM, Ehlert FJ, and Liu-Chen LY (2015) Intrinsic relative activities of $\kappa$ opioid agonists in activating $\mathrm{G} \alpha$ proteins and internalizing receptor: differences between human and mouse receptors. Eur J Pharmacol 761:235-244.

Dönselmann Im Sande P, Hopster K, and Kästner S (2017) [Effects of morphine, butorphanol and levomethadone in different doses on thermal nociceptive thresholds in horses]. Tierarztl Prax Ausg G Grosstiere Nutztiere 45:98-106.

DosSantos MF, Holanda-Afonso RC, Lima RL, DaSilva AF, and Moura-Neto V (2014) The role of the blood-brain barrier in the development and treatment of migraine and other pain disorders. Front Cell Neurosci 8:302.

Dunn AD, Reed B, Erazo J, Ben-Ezra A, and Kreek MJ (2019) Signaling properties of structurally diverse kappa opioid receptor ligands: toward in vitro models of in vivo responses. ACS Chem Neurosci 10:3590-3600.

Dunn AD, Reed B, Guariglia C, Dunn AM, Hillman JM, and Kreek MJ (2018) Structurally related kappa opioid receptor agonists with substantial differential signaling bias: neuroendocrine and behavioral effects in C57BL6 mice. Int J Neuropsychopharmacol 21:847-857.

Dykstra LA, Gmerek DE, Winger G, and Woods JH (1987) Kappa opioids in rhesus monkeys. I. Diuresis, sedation, analgesia and discriminative stimulus effects. $J$ Pharmacol Exp Ther 242:413-420.

Ehrich JM, Messinger DI, Knakal CR, Kuhar JR, Schattauer SS, Bruchas MR, Zweifel LS, Kieffer BL, Phillips PE, and Chavkin C (2015) Kappa opioid receptorinduced aversion requires p38 MAPK activation in VTA dopamine neurons. $J$ Neurosci 35:12917-12931.

Ehrlich AT, Semache M, Gross F, Da Fonte DF, Runtz L, Colley C, Mezni A, Le Gouill C, Lukasheva V, Hogue M, et al. (2019) Biased signaling of the mu opioid receptor revealed in native neurons. iScience 14:47-57.

Endoh T, Matsuura H, Tajima A, Izumimoto N, Tajima C, Suzuki T, Saitoh A, Suzuki T, Narita M, Tseng L, et al. (1999) Potent antinociceptive effects of TRK-820, a novel kappa-opioid receptor agonist. Life Sci 65:1685-1694.

Endoh T, Tajima A, Suzuki T, Kamei J, Narita M, Tseng L, and Nagase H (2000) Characterization of the antinociceptive effects of TRK- 820 in the rat. Eur $J$ Pharmacol 387:133-140.

Erli F, Guerrieri E, Ben Haddou T, Lantero A, Mairegger M, Schmidhammer H, and Spetea M (2017) Highly potent and selective new diphenethylamines interacting with the к-opioid receptor: synthesis, pharmacology, and structure-activity relationships. J Med Chem 60:7579-7590.

Ewald AWM, Bosch PJ, Culverhouse A, Crowley RS, Neuenswander B, Prisinzano TE, and Kivell BM (2017) The C-2 derivatives of salvinorin A, ethoxymethyl ether Sal B and $\beta$-tetrahydropyran Sal B, have anti-cocaine properties with minimal side effects. Psychopharmacology (Berl) 234:2499-2514.

Fantegrossi WE, Kugle KM, Valdes LJ III, Koreeda M, and Woods JH (2005) Kappa-opioid receptor-mediated effects of the plant-derived hallucinogen, salvinorin A, on inverted screen performance in the mouse. Behav Pharmacol 16:627-633.

Ferracane MJ, Brice-Tutt AC, Coleman JS, Simpson GG, Wilson LL, Eans SO, Stacy HM, Murray TF, McLaughlin JP, and Aldrich JV (2020) Design, synthesis, and characterization of the macrocyclic tetrapeptide cyclo[Pro-Sar-Phe-d-Phe]: a mixed opioid receptor agonist-antagonist following oral administration. ACS Chem Neurosci 11:1324-1336.

Fichna J, Dicay M, Lewellyn K, Janecka A, Zjawiony JK, MacNaughton WK and Storr MA (2012) Salvinorin A has antiinflammatory and antinociceptive effects in experimental models of colitis in mice mediated by KOR and CB1 receptors. Inflamm Bowel Dis 18:1137-1145.

Fillingim RB, Ness TJ, Glover TL, Campbell CM, Price DD, and Staud R (2004) Experimental pain models reveal no sex differences in pentazocine analgesia in humans. Anesthesiology 100:1263-1270.

Floyd BN, Camilleri M, Busciglio I, Sweetser S, Burton D, Wong GY, Kell S, Khanna S, Hwang S, and Zinsmeister AR (2009) Effect of a kappa-opioid agonist, i.v. JNJ38488502 , on sensation of colonic distensions in healthy male volunteers. Neurogastroenterol Motil 21:281-290.

France CP, Medzihradsky F, and Woods JH (1994) Comparison of kappa opioids in rhesus monkeys: behavioral effects and receptor binding affinities. $J$ Pharmacol Exp Ther 268:47-58.

Frankowski KJ, Hedrick MP, Gosalia P, Li K, Shi S, Whipple D, Ghosh P, Prisinzano TE, Schoenen FJ, Su Y, et al. (2012) Discovery of small molecule kappa opioid receptor agonist and antagonist chemotypes through a HTS and hit refinement strategy. ACS Chem Neurosci 3:221-236.

Freye E, Hartung E, and Schenk GK (1983) Bremazocine: an opiate that induces sedation and analgesia without respiratory depression. Anesth Analg 62: $483-488$
Gallantine EL and Meert TF (2008) Antinociceptive and adverse effects of mu- and kappa-opioid receptor agonists: a comparison of morphine and U50488-H. Basic Clin Pharmacol Toxicol 103:419-427.

Gardell LR, Spencer RH, Chalmers DT, and Menzaghi F (2008) Preclinical profile of CR845: a novel, long-acting peripheral kappa opioid receptor agonist, in Poster Presentation at the International Association for the Study of Pain, Glasgow, UK. http///ir caratherapeutics.com/static-files/396df363-8031-47f6-b903-eca1df1df26f

Gillis A, Gondin AB, Kliewer A, Sanchez J, Lim HD, Alamein C, Manandhar P, Santiago M, Fritzwanker S, Schmiedel F, et al. (2020a) Low intrinsic efficacy for G protein activation can explain the improved side effect profiles of new opioid agonists. Sci Signal 13:eaaz3140.

Gillis A, Sreenivasan V, and Christie MJ (2020b) Intrinsic efficacy of opioid ligands and its importance for apparent bias, operational analysis and therapeutic window. Mol Pharmacol DOI: 10.1124/mol.119.119214 [published ahead of print].

Glazebrook AJ (1952) Actions and uses of methorphinan. BMJ 2:1328-1330.

Goldstein A, Tachibana S, Lowney LI, Hunkapiller M, and Hood L (1979) Dynorphin(1-13), an extraordinarily potent opioid peptide. Proc Natl Acad Sci USA $\mathbf{7 6}$ 6666-6670.

Gottschlich R, Barber A, Bartoszyk GD, and Seyfried CA (1995) The peripherally acting kappa-opiate agonist EMD 61753 and analogues: opioid activity versus peripheral selectivity. Drugs Exp Clin Res 21:171-174.

Greenwald MK and Stitzer ML (1998) Butorphanol agonist effects and acute physical dependence in opioid abusers: comparison with morphine. Drug Alcohol Depend 53: $17-30$.

Grim TW, Acevedo-Canabal A, and Bohn LM (2020) Toward directing opioid receptor signaling to refine opioid therapeutics. Biol Psychiatry 87:15-21.

Gringauz M, Rabinowitz R, Stav A, and Korczyn AD (2001) Tolerance to the analgesic effect of buprenorphine, butorphanol, nalbuphine, and cyclorphan, and crosstolerance to morphine. J Anesth 15:204-209.

Grudt TJ and Williams JT (1993) kappa-Opioid receptors also increase potassium conductance. Proc Natl Acad Sci USA 90:11429-11432.

Gudin J, Fudin J, and Nalamachu S (2016) Levorphanol use: past, present and future. Postgrad Med 128:46-53.

Guida F, Luongo L, Aviello G, Palazzo E, De Chiaro M, Gatta L, Boccella S, Marabese I, Zjawiony JK, Capasso R, et al. (2012) Salvinorin A reduces mechanical allodynia and spinal neuronal hyperexcitability induced by peripheral formalin injection. Mol Pain 8:60.

Gundry J, Glenn R, Alagesan P, and Rajagopal S (2017) A practical guide to approaching biased agonism at $\mathrm{G}$ protein coupled receptors. Front Neurosci 11:17. Gupta A, Gomes I, Bobeck EN, Fakira AK, Massaro NP, Sharma I, Cavé A, Hamm HE, Parello J, and Devi LA (2016) Collybolide is a novel biased agonist of $\mathrm{\kappa}$-opioid receptors with potent antipruritic activity. Proc Natl Acad Sci USA 113: 6041-6046.

Haiying Z, Lijun Z, Yanjun L, Peiwu C, and Aiyu W (2018) Postoperative analgesic effect of different doses of naloxone combined with butorphanol and psychological nursing intervention. Pak J Pharm Sci 31:2229-2234.

Halder A and Agarwal R (2013) Butorphanol in labour analgesia: a prospective cohort study. J Turk Ger Gynecol Assoc 14:221-224

Hall RC (2012) Psychiatric Presentations of Medical Illness: Somatopsychic Disorders, Springer Science \& Business Media, New York.

Han JS and Xie CW (1982) Dynorphin: potent analgesic effect in spinal cord of the rat. Life Sci 31:1781-1784.

Hayes AG and Birch PJ (1988) Reversal by beta-funaltrexamine and 16-methyl cyprenorphine of the antinociceptive effects of opioid agonists in the mouse and Guinea-pig. Neuropharmacology 27:813-816.

Hesselink JMK (2017) CR845 (Difelikefalin), a kappa receptors agonist in phase III by cara therapeutics: a case of 'spin' in scientific writing? J Pharmacol Clin Res 2: 555588 .

Hill R, Disney A, Conibear A, Sutcliffe K, Dewey W, Husbands S, Bailey C, Kelly E, and Henderson G (2018) The novel $\mu$-opioid receptor agonist PZM21 depresse respiration and induces tolerance to antinociception. $\mathrm{Br} J$ Pharmacol $\mathbf{1 7 5}$ $2653-2661$

Ho JH, Stahl EL, Schmid CL, Scarry SM, Aube J, and Bohn LM (2018) G protein signaling-biased agonism at the $\mathrm{\kappa}$-opioid receptor is maintained in striatal neurons. Science Sig 11:eaar4309.

Hooker JM, Munro TA, Béguin C, Alexoff D, Shea C, Xu Y, and Cohen BM (2009) Salvinorin A and derivatives: protection from metabolism does not prolong shortterm, whole-brain residence. Neuropharmacology 57:386-391.

Hughes FM Jr., Shaner BE, Brower JO, Woods RJ, and Dix TA (2013) Development of a peptide-derived orally-active kappa-opioid receptor agonist targeting peripheral pain. Open Med Chem $J$ 7:16-22.

Huskinson SL, Platt DM, Brasfield M, Follett ME, Prisinzano TE, Blough BE, and Freeman KB (2020) Quantification of observable behaviors induced by typical and atypical kappa-opioid receptor agonists in male rhesus monkeys. Psychopharmacology (Berl) 237:2075-2087.

Jacobs BA, Pando MM, Jennings E, Chavera TA, Clarke WP, and Berg KA (2018) Allosterism within $\delta$ opioid- $\kappa$ opioid receptor heteromers in peripheral sensory neurons: regulation of $\kappa$ opioid agonist efficacy. Mol Pharmacol 93:376-386.

Jacobs BA, Pando MM, Jennings EM, Jamshidi RJ, Zamora JC, Chavera TS, Clarke WP, and Berg KA (2019) Signaling characteristics and functional regulation of delta opioid-kappa opioid receptor (DOP-KOP) heteromers in peripheral sensory neurons. Neuropharmacology 151:208-218.

Jamshidi RJ, Jacobs BA, Sullivan LC, Chavera TA, Saylor RM, Prisinzano TE, Clarke WP, and Berg KA (2015) Functional selectivity of kappa opioid receptor agonists in peripheral sensory neurons. J Pharmacol Exp Ther 355:174-182.

John TF, French LG, and Erlichman JS (2006) The antinociceptive effect of salvinorin A in mice. Eur $J$ Pharmacol 545:129-133.

Jutkiewicz EM, Baladi MG, Folk JE, Rice KC, and Woods JH (2006) The convulsive and electroencephalographic changes produced by nonpeptidic delta-opioid 
agonists in rats: comparison with pentylenetetrazol. J Pharmacol Exp Ther 317: 1337-1348.

Kaski SW, White AN, Gross JD, Trexler KR, Wix K, Harland AA, Prisinzano TE, Aube J, Kinsey SG, Kenakin T, et al. (2019) Preclinical testing of nalfurafine as an opioid-sparing adjuvant that potentiates analgesia by the mu opioid receptortargeting agonist morphine. J Pharmacol Exp Ther 371:487-499 DOI: 10.1124/ jpet.118.255661 [published ahead of print].

Keats AS and Telford J (1956) Nalorphine, a potent analgesic in man. J Pharmacol Exp Ther 117:190-196.

Keïta H, Kayser V, and Guilbaud G (1995) Antinociceptive effect of a к-opioid receptor agonist that minimally crosses the blood-brain barrier (ICI 204448) in a rat model of mononeuropathy. Eur J Pharmacol 277:275-280.

Kenakin T (2014) What is pharmacological 'affinity'? Relevance to biased agonism and antagonism. Trends Pharmacol Sci 35:434-441.

Kivell BM, Paton KF, Kumar N, Morani AS, Culverhouse A, Shepherd A, Welsh SA, Biggerstaff A, Crowley RS, and Prisinzano TE (2018) Kappa opioid receptor agonist mesyl sal B attenuates behavioral sensitization to cocaine with fewer aversive sideeffects than salvinorin A in rodents. Molecules 23:2602.

Kivell B, Uzelac Z, Sundaramurthy S, Rajamanickam J, Ewald A, Chefer V, Jaligam V, Bolan E, Simonson B, Annamalai B, et al. (2014) Salvinorin A regulates dopamine transporter function via a kappa opioid receptor and ERK1/2-dependent mechanism. Neuropharmacology 86:228-240.

Klein Herenbrink C, Sykes DA, Donthamsetti P, Canals M, Coudrat T, Shonberg J, Scammells PJ, Capuano B, Sexton PM, Charlton SJ, et al. (2016) The role of kinetic context in apparent biased agonism at GPCRs. Nat Commun 7:10842.

Kliewer A, Gillis A, Hill R, Schmiedel F, Bailey C, Kelly E, Henderson G, Christie MJ, and Schulz S (2020) Morphine-induced respiratory depression is independent of $\beta$-arrestin2 signalling. Br J Pharmacol 177:2923-2931.

Koch ED, Kapanadze S, Eerdekens MH, Kralidis G, Létal J, Sabatschus I, and Ahmedzai SH (2019) Cebranopadol, a novel first-in-class analgesic drug candidate: first experience with cancer-related pain for up to 26 weeks. J Pain Symptom Manage 58:390-399.

Kshirsagar S, Gear R, Levine J, and Verotta D (2008) A mechanistic model for the sex-specific response to nalbuphine and naloxone in postoperative pain. $J$ Pharmacokinet Pharmacodyn 35:69-83.

Kudryavtseva NN, Gerrits MA, Avgustinovich DF, Tenditnik MV, and Van Ree JM (2004) Modulation of anxiety-related behaviors by mu- and kappa-opioid receptor agonists depends on the social status of mice. Peptides 25:1355-1363.

Kumagai H, Ebata T, Takamori K, Muramatsu T, Nakamoto H, and Suzuki H (2010) Effect of a novel kappa-receptor agonist, nalfurafine hydrochloride, on severe itch in 337 haemodialysis patients: a Phase III, randomized, double-blind, placebocontrolled study. Nephrol Dial Transplant 25:1251-1257.

Kunihara M, Ohyama M, Nakano M, and Hayashi S (1989) Analgesic activity of spiradoline mesylate (U-62,066E), a kappa opioid agonist in mice. Life Sci 45 $1191-1198$

Lahti RA, Mickelson MM, McCall JM, and Von Voigtlander PF (1985) [3H]U-69593 a highly selective ligand for the opioid kappa receptor. Eur J Pharmacol 109: 281-284.

Lalanne L, Ayranci G, Kieffer BL, and Lutz PE (2014) The kappa opioid receptor: from addiction to depression, and back. Front Psychiatry 5:170.

Lambert D, Bird M, and Rowbotham D (2015) Cebranopadol: a first in-class example of a nociceptin/orphanin FQ receptor and opioid receptor agonist. Br J Anaesth 114: $364-366$.

La Regina A, Petrillo P, Sbacchi M, and Tavani A (1988) Interaction of U-69,593 with mu-, alpha- and kappa-opioid binding sites and its analgesic and intestinal effects in rats. Life Sci 42.293-301.

Lasagna L and Beecher HK (1954) The analgesic effectiveness of nalorphine and nalorphine-morphine combinations in man. J Pharmacol Exp Ther 112:356-363.

Lattanzi R, Rief S, Schmidhammer H, Negri L, and Spetea M (2018) In vitro and in vivo pharmacological activities of $14-O$-phenylpropyloxymorphone, a potent mixed $\mathrm{mu} / \mathrm{delta} / \mathrm{kappa}$-opioid receptor agonist with reduced constipation in mice. Front Pharmacol 9:1002.

Leander JD (1983) Evidence that nalorphine, butorphanol and oxilorphan are partial agonists at a к-opioid receptor. Eur J Pharmacol 86:467-470.

Le Rouzic V, Narayan A, Hunkle A, Marrone GF, Lu Z, Majumdar S, Xu J, Pan YX, and Pasternak GW (2019) Pharmacological characterization of levorphanol, a G-protein biased opioid analgesic. Anesth Analg 128:365-373.

Linz K, Christoph T, Tzschentke TM, Koch T, Schiene K, Gautrois M, Schröder W, Kögel BY, Beier H, Englberger W, et al. (2014) Cebranopadol: a novel potent analgesic nociceptin/orphanin FQ peptide and opioid receptor agonist. J Pharmacol Exp Ther 349:535-548.

Linz K, Schröder W, Frosch S, and Christoph T (2017) Opioid-type respiratory depressant side effects of cebranopadol in rats are limited by its nociceptin/orphanin FQ peptide receptor agonist activity. Anesthesiology 126:708-715.

Liu JJ, Chiu YT, DiMattio KM, Chen C, Huang P, Gentile TA, Muschamp JW, Cowan A, Mann M, and Liu-Chen LY (2019a) Phosphoproteomic approach for agonistspecific signaling in mouse brains: $\mathrm{mTOR}$ pathway is involved in $\kappa$ opioid aversion Neuropsychopharmacology 44:939-949.

Liu SS, Pickens S, Burma NE, Ibarra-Lecue I, Yang H, Xue L, Cook C, Hakimian JK Severino AL, Lueptow L, et al. (2019b) Kappa opioid receptors drive a tonic aversive component of chronic pain. J Neurosci 39:4162-4178.

Livingston KE, Stanczyk MA, Burford NT, Alt A, Canals M, and Traynor JR (2018) Pharmacologic evidence for a putative conserved allosteric site on opioid receptors. Mol Pharmacol 93:157-167.

Lötsch J, Ditterich W, Hummel T, and Kobal G (1997) Antinociceptive effects of the kappa-opioid receptor agonist RP 60180 compared with pentazocine in an experimental human pain model. Clin Neuropharmacol 20:224-233.

Lovell KM, Frankowski KJ, Stahl EL, Slauson SR, Yoo E, Prisinzano TE, Aubé J, and Bohn LM (2015) Structure-activity relationship studies of functionally selective kappa opioid receptor agonists that modulate ERK 1/2 phosphorylation while preserving G protein over Barrestin2 signaling bias. ACS Chem Neurosci 6: $1411-1419$.

Lutz PE and Kieffer BL (2013) Opioid receptors: distinct roles in mood disorders Trends Neurosci 36:195-206.

Machelska H, Pflüger M, Weber W, Piranvisseh-Völk M, Daubert JD, Dehaven R, and Stein C (1999) Peripheral effects of the kappa-opioid agonist EMD 61753 on pain and inflammation in rats and humans. $J$ Pharmacol Exp Ther 290:354-361.

Mague SD, Pliakas AM, Todtenkopf MS, Tomasiewicz HC, Zhang Y, Stevens WC Jr., Jones RM, Portoghese PS, and Carlezon WA Jr. (2003) Antidepressant-like effects of kappa-opioid receptor antagonists in the forced swim test in rats. J Pharmacol Exp Ther 305:323-330.

Majumdar S and Devi LA (2018) Strategy for making safer opioids bolstered. Nature 553:286-288.

Maldonado R, Saiardi A, Valverde O, Samad TA, Roques BP, and Borrelli E (1997) Absence of opiate rewarding effects in mice lacking dopamine D2 receptors. Nature 388:586-589.

Manglik A, Lin H, Aryal DK, McCorvy JD, Dengler D, Corder G, Levit A, Kling RC, Bernat V, Hübner H, et al. (2016) Structure-based discovery of opioid analgesics with reduced side effects. Nature 537:185-190.

Massaly N, Copits BA, Wilson-Poe AR, Hipolito L, Markovic T, Yoon HJ, Liu S, Walicki MC, Bhatti DL, Sirohi S, et al. (2019) Pain-induced negative affect is mediated via recruitment of the nucleus accumbens kappa opioid system. Neuron 102:564-573.e6.

McCurdy CR, Sufka KJ, Smith GH, Warnick JE, and Nieto MJ (2006) Antinociceptive profile of salvinorin A, a structurally unique kappa opioid receptor agonist. Pharmacol Biochem Behav 83:109-113.

McDonald J and Lambert D (2005) Opioid receptors. Contin Educ Anaesth Crit Care Pain 5:22-25.

McLaughlin JP, Myers LC, Zarek PE, Caron MG, Lefkowitz RJ, Czyzyk TA, Pintar JE, and Chavkin C (2004) Prolonged kappa opioid receptor phosphorylation mediated by G-protein receptor kinase underlies sustained analgesic tolerance. J Biol Chem 279:1810-1818.

McLaughlin JP, Xu M, Mackie K, and Chavkin C (2003) Phosphorylation of a carboxyl-terminal serine within the kappa-opioid receptor produces desensitization and internalization. $J$ Biol Chem 278:34631-34640.

McNulty JP (2007) Levorphanol for the treatment of severe chronic pain. Int J Pharm Compd 11:202-211.

Meade JA, Alkhlaif Y, Contreras KM, Obeng S, Toma W, Sim-Selley LJ, Selley DE, and Damaj MI (2020) Kappa opioid receptors mediate an initial aversive component of paclitaxel-induced neuropathy. Psychopharmacology (Berl) DOI: 10.1007/ s00213-020-05572-2 [published ahead of print].

Mello NK, Mendelson JH, Sholar MB, Jaszyna-Gasior M, Goletiani N, and Siegel AJ (2005) Effects of the mixed mu/kappa opioid nalbuphine on cocaine-induced changes in subjective and cardiovascular responses in men. Neuropsychopharmacology 30:618-632.

Mello NK and Negus SS (2000) Interactions between kappa opioid agonists and cocaine. Preclinical studies. Ann N Y Acad Sci 909:104-132.

Miaskowski C, Taiwo YO, and Levine JD (1990) к- and $\delta$-opioid agonists synergize to produce potent analgesia. Brain Res 509:165-168

Michel MC and Charlton SJ (2018) Biased agonism in drug discovery-is it too soon to choose a path? Mol Pharmacol 93:259-265.

Miller RR (1975) Clinical effects of pentazocine in hospitalized medical patients. $J$ Clin Pharmacol 15:198-205.

Mores KL, Cummins BR, Cassell RJ, and van Rijn RM (2019) A review of the therapeutic potential of recently developed G protein-biased kappa agonists. Front Pharmacol 10:407.

Mori T, Itoh T, Yoshizawa K, Ise Y, Mizuo K, Saeki T, Komiya S, Masukawa D, Shibasaki M, and Suzuki T (2015) Involvement of $\mu$ - and $\delta$-opioid receptor function in the rewarding effect of ( \pm )-pentazocine. Addict Biol 20:724-732.

Morrison JD, Loan WB, and Dundee JW (1971) Controlled comparison of the efficacy of fourteen preparations in the relief of postoperative pain. BMJ 3:287-290.

Mucha RF and Herz A (1985) Motivational properties of kappa and mu opioid receptor agonists studied with place and taste preference conditioning. Psychopharmacology (Berl) 86:274-280.

Munro TA, Duncan KK, Xu W, Wang Y, Liu-Chen LY, Carlezon WA Jr., Cohen BM, and Béguin C (2008) Standard protecting groups create potent and selective kappa opioids: salvinorin B alkoxymethyl ethers. Bioorg Med Chem 16:1279-1286.

Muntean BS, Zucca S, MacMullen CM, Dao MT, Johnston C, Iwamoto H, Blakely RD Davis RL, and Martemyanov KA (2018) Interrogating the spatiotemporal landscape of neuromodulatory GPCR signaling by real-time imaging of cAMP in intact neurons and circuits. Cell Rep 22:255-268.

Negus SS (2019) Core outcome measures in preclinical assessment of candidate analgesics. Pharmacol Rev 71:225-266.

Negus SS, Mello NK, Portoghese PS, and Lin CE (1997) Effects of kappa opioids on cocaine self-administration by rhesus monkeys. $J$ Pharmacol Exp Ther 282:44-55.

Negus SS, O'Connell R, Morrissey E, Cheng K, and Rice KC (2012) Effects of peripherally restricted $\kappa$ opioid receptor agonists on pain-related stimulation and depression of behavior in rats. J Pharmacol Exp Ther 340:501-509.

Negus SS, Schrode K, and Stevenson GW (2008) Micro/kappa opioid interactions in rhesus monkeys: implications for analgesia and abuse liability. Exp Clin Psychopharmacol 16:386-399.

Neumeyer JL, Bidlack JM, Zong R, Bakthavachalam V, Gao P, Cohen DJ, Negus SS, and Mello NK (2000) Synthesis and opioid receptor affinity of morphinan and benzomorphan derivatives: mixed kappa agonists and mu agonists/antagonists as potential pharmacotherapeutics for cocaine dependence. J Med Chem 43: $114-122$

Olesen AE, Kristensen K, Staahl C, Kell S, Wong GY, Arendt-Nielsen L, and Drewes AM (2013) A population pharmacokinetic and pharmacodynamic study of a peripheral к-opioid receptor agonist CR665 and oxycodone. Clin Pharmacokinet 52: 125-137. 
Ortiz MI, Ponce-Monter H, Fernández-Martínez E, Pérez-Hernández N, Macías A, Rangel-Flores E, and Castañeda-Hernández G (2007) Evaluation of the interaction between acemetacin and opioids on the hargreaves model of thermal hyperalgesia. Pharmacol Biochem Behav 88:47-54

Pandya ST (2010) Labour analgesia: recent advances. Indian J Anaesth 54:400-408

Paton KF, Kumar N, Crowley RS, Harper JL, Prisinzano TE, and Kivell BM (2017) The analgesic and anti-inflammatory effects of Salvinorin A analogue $\beta$-tetrahydropyran Salvinorin B in mice. Eur J Pain 21:1039-1050

Patrick CA, Holden Ko MC, and Woods JH (1999) Comparison of antinociceptive effects induced by kappa opioid agonists in male and female mice. Analgesia (Elmsford N Y) 4:397-404.

Paul D, Pick CG, Tive LA, and Pasternak GW (1991) Pharmacological characterization of nalorphine, a kappa 3 analgesic. J Pharmacol Exp Ther 257:1-7.

Pawar A, Rajalakshmi AK, and Upadhyay RP (2015) Pentazocine use among people who inject drugs in India. Asian $J$ Psychiatr 16:3-6.

Peet MM and Baker LE (2011) Salvinorin B derivatives, EOM-Sal B and MOM-Sal B, produce stimulus generalization in male Sprague-Dawley rats trained to discriminate salvinorin A. Behav Pharmacol 22:450-457.

Pelissier T, Paeile C, Soto-Moyano R, Saavedra H, and Hernández A (1990) Analgesia produced by intrathecal administration of the kappa opioid agonist, U-50,488H, on formalin-evoked cutaneous pain in the rat. Eur J Pharmacol 190:287-293.

Pham TC, Fudin J, and Raffa RB (2015) Is levorphanol a better option than methadone? Pain Med 16:1673-1679.

Pick CG, Paul D, and Pasternak GW (1992) Nalbuphine, a mixed kappa 1 and kappa 3 analgesic in mice. $J$ Pharmacol Exp Ther 262:1044-1050.

Pliakas AM, Carlson RR, Neve RL, Konradi C, Nestler EJ, and Carlezon WA Jr. (2001) Altered responsiveness to cocaine and increased immobility in the forced swim test associated with elevated cAMP response element-binding protein expression in nucleus accumbens. $J$ Neurosci 21:7397-7403.

Porreca F, Mosberg HI, Hurst R, Hruby VJ, and Burks TF (1984) Roles of mu, delta and kappa opioid receptors in spinal and supraspinal mediation of gastrointestinal transit effects and hot-plate analgesia in the mouse. J Pharmacol Exp Ther 230: 341-348.

Pradhan AA, Befort K, Nozaki C, Gavériaux-Ruff C, and Kieffer BL (2011) The delta opioid receptor: an evolving target for the treatment of brain disorders. Trends Pharmacol Sci 32:581-590.

Privette TH and Terrian DM (1995) Kappa opioid agonists produce anxiolytic-like behavior on the elevated plus-maze. Psychopharmacology (Berl) 118:444-450.

Provencher BA, Sromek AW, Li W, Russell S, Chartoff E, Knapp BI, Bidlack JM, and Neumeyer JL (2013) Synthesis and pharmacological evaluation of aminothiazolomorphinans at the mu and kappa opioid receptors. J Med Chem 56 8872-8878.

Raehal KM, Walker JK, and Bohn LM (2005) Morphine side effects in beta-arrestin 2 knockout mice. J Pharmacol Exp Ther 314:1195-1201.

Ranganathan M, Schnakenberg A, Skosnik PD, Cohen BM, Pittman B, Sewell RA, and D'Souza DC (2012) Dose-related behavioral, subjective, endocrine, and psychophysiological effects of the к opioid agonist Salvinorin A in humans. Biol Psychiatry 72:871-879.

Ren MF, Lu CH, and Han JS (1985) Dynorphin-A-(1-13) antagonizes morphine analgesia in the brain and potentiates morphine analgesia in the spinal cord. Peptides 6:1015-1020.

Rives ML, Rossillo M, Liu-Chen LY, and Javitch JA (2012) 6'-Guanidinonaltrindole $\left(6^{\prime}\right.$-GNTI) is a G protein-biased $\kappa$-opioid receptor agonist that inhibits arrestin recruitment. J Biol Chem 287:27050-27054.

Ross NC, Kulkarni SS, McLaughlin JP, and Aldrich JV (2010) Synthesis of CJ15,208, a novel к-opioid receptor antagonist. Tetrahedron Lett 51:5020-5023.

Roth BL, Baner K, Westkaemper R, Siebert D, Rice KC, Steinberg S, Ernsberger P, and Rothman RB (2002) Salvinorin A: a potent naturally occurring nonnitrogenous kappa opioid selective agonist. Proc Natl Acad Sci USA 99:11934-11939.

Rowbotham MC, Twilling L, Davies PS, Reisner L, Taylor K, and Mohr D (2003) Oral opioid therapy for chronic peripheral and central neuropathic pain. $N$ Engl J Med 348:1223-1232.

Ruda MA, Iadarola MJ, Cohen LV, and Young WS III (1988) In situ hybridization histochemistry and immunocytochemistry reveal an increase in spinal dynorphin biosynthesis in a rat model of peripheral inflammation and hyperalgesia. Proc Natl Acad Sci USA 85:622-626.

Rusin KI, Giovannucci DR, Stuenkel EL, and Moises HC (1997) Kappa-opioid receptor activation modulates $\mathrm{Ca} 2+$ currents and secretion in isolated neuroendocrine nerve terminals. J Neurosci 17:6565-6574.

Sadove M, Balagot RC, and Pecora FN (1964) Pentazocine--a new nonaddicting analgesic. Preliminary single-blind study. JAMA 189:199-202.

Schattauer SS, Kuhar JR, Song A, and Chavkin C (2017) Nalfurafine is a G-protein biased agonist having significantly greater bias at the human than rodent form of the kappa opioid receptor. Cell Signal 32:59-65.

Schiene K, Schröder W, Linz K, Frosch S, Tzschentke TM, Jansen U, and Christoph T (2018) Nociceptin/orphanin FQ opioid peptide (NOP) receptor and $\mu$-opioid peptide (MOP) receptors both contribute to the anti-hypersensitive effect of cebranopado in a rat model of arthritic pain. Eur $J$ Pharmacol 832:90-95.

Schlosburg JE, Whitfield TW Jr., Park PE, Crawford EF, George O, Vendruscolo LF, and Koob GF (2013) Long-term antagonism of $\kappa$ opioid receptors prevents escalation of and increased motivation for heroin intake. J Neurosci 33: 19384-19392.

Schmid CL, Streicher JM, Groer CE, Munro TA, Zhou L, and Bohn LM (2013) Functional selectivity of $6^{\prime}$-guanidinonaltrindole $\left(6^{\prime}\right.$-GNTI) at к-opioid receptors in striatal neurons. J Biol Chem 288:22387-22398.

Schmidt WK, Tam SW, Shotzberger GS, Smith DH Jr., Clark R, and Vernier VG (1985) Nalbuphine. Drug Alcohol Depend 14:339-362.

Scholl L, Seth P, Kariisa M, Wilson N, and Baldwin G (2018) Drug and opioidinvolved overdose deaths - United States, 2013-2017. MMWR Morb Mortal Wkly Rep 67:1419-1427.
Scholz A, Bothmer J, Kok M, Hoschen K, and Daniels S (2018) Cebranopadol: a novel, first-in-class, strong analgesic: results from a randomized phase IIa clinical trial in postoperative acute pain. Pain Physician 21:E193-E206.

Schulz R, Wehmeyer A, and Schulz K (2002) Visualizing preference of G proteincoupled receptor kinase 3 for the process of kappa-opioid receptor sequestration. Mol Pharmacol 61:1444-1452.

Schunk S, Linz K, Hinze C, Frormann S, Oberbörsch S, Sundermann B, Zemolka S, Englberger W, Germann T, Christoph T, et al. (2014) Discovery of a potent analgesic NOP and opioid receptor agonist: cebranopadol. ACS Med Chem Lett 5 857-862.

Shaw JS, Carroll JA, Alcock P, and Main BG (1989) ICI 204448: a kappa-opioid agonist with limited access to the CNS. Br J Pharmacol 96:986-992.

Sherwood AM, Crowley RS, Paton KF, Biggerstaff A, Neuenswander B, Day VW, Kivell BM, and Prisinzano TE (2017) Addressing structural flexibility at the A-ring on salvinorin A: discovery of a potent kappa-opioid agonist with enhanced metabolic stability. J Med Chem 60:3866-3878.

Shippenberg TS, Chefer VI, and Thompson AC (2009) Delta-opioid receptor antagonists prevent sensitization to the conditioned rewarding effects of morphine. Biol Psychiatry 65:169-174.

Sibille KT, Kindler LL, Glover TL, Gonzalez RD, Staud R, Riley JL III, and Fillingim RB (2011) Individual differences in morphine and butorphanol analgesia: a laboratory pain study. Pain Med 12:1076-1085.

Simonin F, Gavériaux-Ruff C, Befort K, Matthes H, Lannes B, Micheletti G, Matté MG, Charron G, Bloch B, and Kieffer B (1995) kappa-Opioid receptor in humans: cDNA and genomic cloning, chromosomal assignment, functional expression, pharmacology, and expression pattern in the central nervous system. Proc Natl Acad Sci USA 92:7006-7010.

Simonin F, Valverde O, Smadja C, Slowe S, Kitchen I, Dierich A, Le Meur M, Roques BP, Maldonado R, and Kieffer BL (1998) Disruption of the kappa-opioid receptor gene in mice enhances sensitivity to chemical visceral pain, impairs pharmacological actions of the selective kappa-agonist U-50,488H and attenuates morphine withdrawal. EMBO J 17:886-897.

Simonson B, Morani AS, Ewald AW, Walker L, Kumar N, Simpson D, Miller JH, Prisinzano TE, and Kivell BM (2015) Pharmacology and anti-addiction effects of the novel $\kappa$ opioid receptor agonist Mesyl Sal B, a potent and long-acting analogue of salvinorin A. Br J Pharmacol 172:515-531.

Singh PM, Johnson CB, Gartrell B, Mitchinson S, Jacob A, and Chambers P (2017) Analgesic effects of morphine and butorphanol in broiler chickens. Vet Anaesth Analg 44:538-545.

Skoubis PD, Matthes HW, Walwyn WM, Kieffer BL, and Maidment NT (2001) Naloxone fails to produce conditioned place aversion in mu-opioid receptor knock-out mice. Neuroscience 106:757-763.

Spetea M, Berzetei-Gurske IP, Guerrieri E, and Schmidhammer H (2012) Discovery and pharmacological evaluation of a diphenethylamine derivative (HS665), a highly potent and selective $\kappa$ opioid receptor agonist. $J$ Med Chem 55: 10302-10306.

Spetea M, Eans SO, Ganno ML, Lantero A, Mairegger M, Toll L, Schmidhammer H, and McLaughlin JP (2017) Selective $\kappa$ receptor partial agonist HS666 produces potent antinociception without inducing aversion after i.c.v. administration in mice. Br J Pharmacol 174:2444-2456.

Stahl EL, Zhou L, Ehlert FJ, and Bohn LM (2015) A novel method for analyzing extremely biased agonism at G protein-coupled receptors. Mol Pharmacol 87: 866-877.

Stevens CW (1996) Relative analgesic potency of mu, delta and kappa opioids after spinal administration in amphibians. $J$ Pharmacol Exp Ther 276:440-448.

Stevenson GW, Wentland MP, Bidlack JM, Mello NK, and Negus SS (2004) Effects of the mixed-action $\kappa / \mu$ opioid agonist 8-carboxamidocyclazocine on cocaine- and foodmaintained responding in rhesus monkeys. Eur $J$ Pharmacol 506:133-141.

Stringer M, Makin MK, Miles J, and Morley JS (2000) d-morphine, but not l-morphine, has low micromolar affinity for the non-competitive N-methyl-D-aspartate site in rat forebrain. Possible clinical implications for the management of neuropathic pain. Neurosci Lett 295:21-24.

Sun JF, Wang YH, Li FY, Lu G, Tao YM, Cheng Y, Chen J, Xu XJ, Chi ZQ, Neumeyer JL, et al. (2010) Effects of ATPM-ET, a novel $\kappa$ agonist with partial $\mu$ activity, on physical dependence and behavior sensitization in mice. Acta Pharmacol Sin 31: $1547-1552$

Suzuki S, Sugawara Y, Inada H, Tsuji R, Inoue A, Tanimura R, Shimozono R, Konno M, Ohyama T, Higashi E, et al. (2017) Discovery of peripheral к-opioid receptor agonists as novel analgesics. Chem Pharm Bull (Tokyo) 65:1085-1088.

Suzuki T, Shiozaki Y, Masukawa Y, Misawa M, and Nagase H (1992) The role of muand kappa-opioid receptors in cocaine-induced conditioned place preference. Jpn $J$ Pharmacol 58:435-442.

Tang Y, Yang J, Lunzer MM, Powers MD, and Portoghese PS (2010) A к opioid pharmacophore becomes a spinally selective $\kappa-\delta$ agonist when modified with a basic extender arm. ACS Med Chem Lett 2:7-10.

Taussig R, Iñiguez-Lluhi JA, and Gilman AG (1993) Inhibition of adenylyl cyclase by Gi alpha. Science 261:218-221.

Tennant FS Jr., Tate JA, and Ruckel E (1976) Clinical trial in post-addicts with oxilorphan (levo-BC-2605): a new narcotic antagonist. Drug Alcohol Depend 1 $329-337$.

Ulker E, Toma W, White A, Uprety R, Majumdar S, and Damaj MI (2020) The antinociceptive effects of a dual kappa-delta opioid receptor agonist in the mouse formalin test. Behav Pharmacol 31:174-178.

Ur E, Wright DM, Bouloux PM, and Grossman A (1997) The effects of spiradoline (U$62066 \mathrm{E})$, a kappa-opioid receptor agonist, on neuroendocrine function in man. $\mathrm{Br}$ $J$ Pharmacol 120:781-784

Valdés LJ III (1994) Salvia divinorum and the unique diterpene hallucinogen, Salvinorin (divinorin) A. J Psychoactive Drugs 26:277-283.

Vallejo R, Barkin RL, and Wang VC (2011) Pharmacology of opioids in the treatment of chronic pain syndromes. Pain Physician 14:E343-E360. 
Vanderah TW, Largent-Milnes T, Lai J, Porreca F, Houghten RA, Menzaghi F, Wisniewski K, Stalewski J, Sueiras-Diaz J, Galyean R, et al. (2008) Novel D-amino acid tetrapeptides produce potent antinociception by selectively acting at peripheral kappa-opioid receptors. Eur J Pharmacol 583:62-72.

Váradi A, Marrone GF, Eans SO, Ganno ML, Subrath JJ, Le Rouzic V, Hunkele A, Pasternak GW, McLaughlin JP, and Majumdar S (2015) Synthesis and characterization of a dual kappa-delta opioid receptor agonist analgesic blocking cocaine reward behavior. ACS Chem Neurosci 6:1813-1824.

Váradi A, Marrone GF, Palmer TC, Narayan A, Szabó MR, Le Rouzic V, Grinnell SG, Subrath JJ, Warner E, Kalra S, et al. (2016) Mitragynine/corynantheidine pseudoindoxyls as opioid analgesics with mu agonism and delta antagonism, which do not recruit $\beta$-arrestin-2. J Med Chem 59:8381-8397.

Varghese V and Hudlicky T (2014) A short history of the discovery and development of naltrexone and other morphine derivatives. Natural Products in Medicinal Chemistry 225-250, Wiley-VCH, Weinheim, Germany.

Vonvoigtlander PF, Lahti RA, and Ludens JH (1983) U-50,488: a selective and structurally novel non-Mu (kappa) opioid agonist. J Pharmacol Exp Ther 224:7-12.

Von Voigtlander PF and Lewis RA (1982) U-50,488, a selective kappa opioid agonist: comparison to other reputed kappa agonists. Prog Neuropsychopharmacol Biol Psychiatry 6:467-470.

Vonvoigtlander PF and Lewis RA (1988) Analgesic and mechanistic evaluation of spiradoline, a potent kappa opioid. J Pharmacol Exp Ther 246:259-262.

Vunck SA, Snider SE, van den Oord EJCG, and Beardsley PM (2011) The kappa opioid receptor agonist, U50,488, exacerbates conditioned fear in mice. FASEB $J$ 25:617.

Wadenberg ML (2003) A review of the properties of spiradoline: a potent and selective kappa-opioid receptor agonist. CNS Drug Rev 9:187-198.

Waldhoer M, Fong J, Jones RM, Lunzer MM, Sharma SK, Kostenis E, Portoghese PS, and Whistler JL (2005) A heterodimer-selective agonist shows in vivo relevance of G protein-coupled receptor dimers. Proc Natl Acad Sci USA 102:9050-9055.

Wang YH, Sun JF, Tao YM, Chi ZQ, and Liu JG (2010) The role of kappa-opioid receptor activation in mediating antinociception and addiction. Acta Pharmacol Sin 31:1065-1070.

Wang YJ, Hang A, Lu YC, Long Y, Zan GY, Li XP, Wang Q, Zhao ZX, He L, Chi ZQ, et al. (2016) к Opioid receptor activation in different brain regions differentially modulates anxiety-related behaviors in mice. Neuropharmacology 110:92-101.

Wang YJ, Tao YM, Li FY, Wang YH, Xu XJ, Chen J, Cao YL, Chi ZQ, Neumeyer JL, Zhang A, et al. (2009) Pharmacological characterization of ATPM [(-)-3-aminothiazolo[5,4-b]-N-cyclopropylmethylmorphinan hydrochloride], a novel mixed kappa-agonist and mu-agonist/-antagonist that attenuates morphine antinociceptive tolerance and heroin self-administration behavior. J Pharmacol Exp Ther 329:306-313.

Wang Z, Gardell LR, Ossipov MH, Vanderah TW, Brennan MB, Hochgeschwender U, Hruby VJ, Malan TP Jr., Lai J, and Porreca F (2001) Pronociceptive actions of dynorphin maintain chronic neuropathic pain. J Neurosci 21:1779-1786.

Wee S and Koob GF (2010) The role of the dynorphin-kappa opioid system in the reinforcing effects of drugs of abuse. Psychopharmacology (Berl) 210:121-135.

White KL, Robinson JE, Zhu H, DiBerto JF, Polepally PR, Zjawiony JK, Nichols DE, Malanga CJ, and Roth BL (2015) The G protein-biased k-opioid receptor agonist RB-64 is analgesic with a unique spectrum of activities in vivo. $J$ Pharmacol Exp Ther 352:98-109.
White KL, Scopton AP, Rives ML, Bikbulatov RV, Polepally PR, Brown PJ, Kenakin T, Javitch JA, Zjawiony JK, and Roth BL (2014) Identification of novel functionally selective к-opioid receptor scaffolds. Mol Pharmacol 85:83-90.

Williams DA, Zheng Y, David BG, Yuan Y, Zaidi SA, Stevens DL, Scoggins KL, Selley

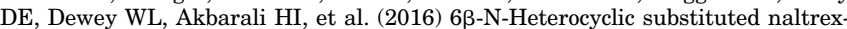
amine derivative BNAP: a peripherally selective mixed MOR/KOR ligand. ACS Chem Neurosci 7:1120-1129.

Wilson JL, Nayanar V, and Walker JS (1996) The site of anti-arthritic action of the kappa-opioid, U-50, 488H, in adjuvant arthritis: importance of local administration. $\mathrm{Br}$ J Pharmacol 118:1754-1760.

Wong CL and Wai MK (1984) Increased naloxone potency induced by pretreatment with morphine and nalbuphine in mice. Clin Exp Pharmacol Physiol 11:301-307.

Yadav J, Regmi MC, Basnet P, Guddy KM, Bhattarai B, and Poudel P (2018) Butorphanol in labour analgesia. JNMA J Nepal Med Assoc 56:940-944.

Yan F, Bikbulatov RV, Mocanu V, Dicheva N, Parker CE, Wetsel WC, Mosier PD, Westkaemper RB, Allen JA, Zjawiony JK, et al. (2009) Structure-based design, synthesis, and biochemical and pharmacological characterization of novel salvinorin A analogues as active state probes of the kappa-opioid receptor. Biochemistry 48:6898-6908.

Yekkirala AS, Lunzer MM, McCurdy CR, Powers MD, Kalyuzhny AE, Roerig SC, and Portoghese PS (2011) N-naphthoyl-beta-naltrexamine (NNTA), a highly selective and potent activator of $\mu /$ kappa-opioid heteromers. Proc Natl Acad Sci USA 108:5098-5103.

Yoa-Pu HO, Wang J-J, and Shung-Tai H (1998) inventors, Nalbuphine esters having long acting analgesic action and method of use. U.S. patent 5,750,534.

Zangrandi L, Burtscher J, MacKay JP, Colmers WF, and Schwarzer C (2016) The G-protein biased partial $\kappa$ opioid receptor agonist 6 '-GNTI blocks hippocampal paroxysmal discharges without inducing aversion. Br J Pharmacol 173:1756-1767.

Zhang LS, Wang J, Chen JC, Tao YM, Wang YH, Xu XJ, Chen J, Xu YG, Xi T, $\mathrm{Hu} \mathrm{XW}$, et al. (2015) Novel $\kappa$-opioid receptor agonist MB-1C-OH produces potent analgesia with less depression and sedation. Acta Pharmacol Sin 36: $565-571$.

Zhang Y, Butelman ER, Schlussman SD, Ho A, and Kreek MJ (2005) Effects of the plant-derived hallucinogen salvinorin A on basal dopamine levels in the caudate putamen and in a conditioned place aversion assay in mice: agonist actions at kappa opioid receptors. Psychopharmacology (Berl) 179:551-558.

Zhou L, Lovell KM, Frankowski KJ, Slauson SR, Phillips AM, Streicher JM, Stahl E, Schmid CL, Hodder P, Madoux F, et al. (2013) Development of functionally selective, small molecule agonists at kappa opioid receptors. J Biol Chem 288: 36703-36716.

Zimmerman DM, Leander JD, Reel JK, and Hynes MD (1987) Use of betafunaltrexamine to determine mu opioid receptor involvement in the analgesic activity of various opioid ligands. J Pharmacol Exp Ther 241:374-378.

Zorn KE and Fudin J (2011) Treatment of neuropathic pain: the role of unique opioid agents. Pract Pain Manag 11:26-33.

Address correspondence to: Bronwyn M. Kivell, School of Biological Sciences, Centre for Biodiscovery, Victoria University of Wellington, PO Box 600, Wellington 6140, New Zealand. E-mail: bronwyn.kivell@vuw.ac.nz 